\section{DENSIFICACIÓN (NO) PLANIFICADA DE UNA METRÓPOLI. EL CASO DEL ÁREA METROPOLITANA DE LIMA 2000-2014'}

Viktor Bensús Talavera²

\section{Resumen}

La discusión sobre el boom inmobiliario en el Perú, iniciado en el 2006, se ha concentrado en su rol dinamizador de la economía nacional, obviando sus implicancias en el acceso a vivienda para los más pobres y sus efectos socioespaciales. Esta investigación parte del análisis de los principales cambios en políticas y normativa a distintas escalas de gobierno que han modificado las características de la gestión urbana a escala local en el Área Metropolitana de Lima-AML. En un segundo momento, se analiza la oferta formal de departamentos, principal producto inmobiliario en el AML, y dos relevantes cambios socioespaciales que conlleva: la intensificación de patrones de segregación y

\section{(NON)PLANNED DENSIFICATION OF A METROPOLIS. THE CASE OF THE METROPOLITAN AREA OF LIMA, 2000-2014'}

Viktor Bensús Talavera²

\section{Abstract}

The debate on the Peruvian real estate boom, which began in 2006, focuses on its role in driving the national economy, ignoring its consequences on the access to housing for vulnerable people and its socio-spatial effects. This research starts with analysis of the main policy and regulatory changes that have been taking place at different governmental levels, which have also modified the characteristics of local urban management within the Metropolitan Area of Lima (LMA). It then explores the formal supply of apartments -which are regarded as the main real estate product within the MAL, and two major socio-spatial consequences associated with 
la extensión de un modelo compacto de ciudad. Se sugiere que estas dinámicas son resultado de la interacción, conjugación y disputa de intereses de distintos gobiernos nacionales, metropolitanos y locales, así como de actores inmobiliarios, bancos y la demanda de vivienda. Para ello, se recurrió a la sistematización y análisis de información censal y de la actividad edificadora del mercado formal entre 2000 y 2014. Esto se complementa con información cualitativa obtenida a través de entrevistas y un análisis espacial realizado con sistemas de información geográfica.

PALABRAS CLAVE: DENSIFICACIÓN HABITACIONAL, MERCADO INMOBILIARIO, VIVIENDA， GESTIÓN URBANA, LIMA.

Recibido: 04-03-2016

Aceptado: 11-12-2017

1 La Dirección General de Investigación-PUCP apoyó esta investigación a partir de los proyectos "Gestión urbana de los distritos de Lima: ¿al servicio de vecinos o de ciudadanos?" (2012), “Gestión local de la densificación urbana de Lima: desafíos para la gobernabilidad de una metrópoli emergente" (2013), y "La densificación urbana en el siglo XXI como desafío para la planificación de Lima Metropolitana" (2013-2015).

2 Perú. Pontificia Universidad Católica del Perú. Correo electrónico:vbensus@pucp.pe. this process: the intensification of segregation patterns and an extension of the compact city model. It is suggested that these dynamics are the result of the interaction, convergence and conflicts of interests among different national, metropolitan and local governments and among real estate actors, banks and the demand for housing. To this end, this paper systematizes and analyzes census information and data of formal building activity over the period 2000 to 2014. This is complemented by qualitative information obtained through interviews and a spatial analysis supported by geographic information systems.

KEYWORDS: HOUSING DENSITY, REAL ESTATE MARKET, HOUSING, URBAN MANAGEMENT, LIMA.

Received: 04-03-2016

Accepted: 11-12-2017

1 Research based on the projects "Urban management of Lima districts: Who is it aimed at: Neighbors or citizens?" (2012), "Local management of urban densification in Lima: Challenges for the governance of an emerging metropolis" (2013) and "Urban densification in the 21st century and its challenges for the planning of metropolitan Lima" (2013-2015), funded by the Directorate-General for Research-PCUP.

2 Peru. Pontifical Catholic University of Peru. Email: vbensus@ pucp.pe. 


\section{Introducción}

De acuerdo con diversos autores, en las últimas décadas las ciudades latinoamericanas vienen experimentando importantes transformaciones socio-espaciales (Mattos, 2002; Ciccolella y Mignaqui, 2009). Estas transformaciones, que incluyen fragmentación urbana, policentrismo, segregación socio-espacial, entre otros fenómenos, son el resultado del proceso de expansión de mercados a escala global iniciado en la década de 1970, e implantado en la región en las décadas de 1980 y 1990 (Mattos, 2008; Portes \& Roberts, 2005; Abramo, 2012; Ugarteche y Martinez-Ávila, 2013). Dicho proceso va acompañado de una re-territorialización (Brenner, 1998), que implica la reorganización de las jerarquías y la gestión territoriales, y que se plasma a través de procesos de descentralización. De esta manera, los gobiernos locales han asumido un rol más importante tanto para la atracción como para el control de flujos económicos (Mattos, 2008; Basualdo, 2013).

Estas dinámicas se caracterizan, en lo económico, por combinar liberalización de mercados, apertura fiscal y la necesidad de gobiernos locales de generar mayores recursos propios para poder gestionar sus territorios. En la dimensión espacial, el mercado se vuelve el principal elemento en la producción social del territorio - característica determinante de lo que distintos autores han llamado la "ciudad neoliberal" (Abramo, 2012; Janoshchka e

\section{Introduction}

According to diverse authors, Latin American cities have been experiencing major sociospatial transformations over the last decades (Mattos, 2002; Ciccolella and Mignaqui, 2009). These transformations, which include urban fragmentation, polycentrism and socio-spatial segregation, amongst other phenomena, are the result of the global expansion of markets -a process that began during the 1970s and then implemented in the region during the 1980s and 1990s (Mattos, 2008; Portes and Roberts, 2005; Abramo, 2012; Ugarteche and MartinezÁvila, 2013). Such a process also involved the emergence of reterritorialization (Brenner, 1998), that is the reorganization of hierarchies and territorial management which are then reflected in decentralization processes. In this way, local governments have assumed a major role when it comes to attracting and controlling economic flows (Mattos, 2008; Basualdo, 2013).

In economic terms, these dynamics are characterized by the convergence of market liberalization, fiscal openness and the needs of governments to generate greater resources for territorial management purposes. In spatial terms, the market becomes the main element within the context of the social production of territory $-a$ defining characteristic of the so-called "neoliberal city" (Abramo, 2012; 
Hidalgo, 2014). Este nuevo tipo de ciudad implica, entre otros fenómenos, la agudización de la oferta inmobiliaria especulativa tanto en mercados formales como informales (Mattos, 2002).

Ahora bien, los mercados formal e informal no se desarrollan por separado, sino que se influencian mutuamente (Rodríguez, 1969; Jaramillo, 2003; Roy, 2005). De hecho, Abramo (2012) sugiere que en Latinoamérica la convivencia de ambos mercados ha conllevado una morfología particular de las grandes ciudades de la región: en ella se conjuga un modelo compacto de producción de ciudad con uno disperso o difuso. El primer modelo estaría más relacionado al mercado formal, mientras que el segundo, al informal (Abramo, 2012). En otras palabras, el proceso de producción de la ciudad latinoamericana no respondería necesariamente a directrices de planificación, sino a las lógicas de los mercados formales e informales.

La identificación del vínculo entre ambos mercados no es algo reciente, por el contrario, ha sido objeto de investigación de gran parte de estudios sobre la urbanización de las grandes ciudades de la región desde mediados del siglo pasado (Deler, 1975; Calderón, 1999). Sin embargo, estas investigaciones se concentraron principalmente en comprender el modo informal de acceso a vivienda y urbanización. El caso del Área Metropolitana de Lima -AML, donde se centra esta investigación, no fue ajeno a este enfoque y la mayor parte de
Janoshchka and Hidalgo, 2014). Amongst other phenomena, this new type of city implies the intensification of real estate speculation both in formal and informal markets (Mattos, 2002).

However, formal and informal markets do not operate independently but influence each other (Rodríguez, 1969; Jaramillo, 2003; Roy, 2005). In fact, Abramo (2012) suggests that, within the Latin American context, the coexistence between these two markets has generated a particular morphology in large cities: these are spaces where compact city models and dispersed or diffused city models converge. While the first of these models is associated with the formal market, the second model is related to the informal market (Abramo, 2012). In other words, the productive process of Latin American cities is not necessarily governed by planning guidelines, but by the principles of formal and informal markets.

The identification of a relationship between both markets is not recent; on the contrary, it has been explored by an important number of studies about the urban development of large Latin American cities since the mid-20 th century (Deler, 1975; Calderón, 1999). However, these studies are mainly focused on understanding the informal access to housing and urban development. The case Metropolitan Area of Lima, MAL, which is the focus of this research, 
trabajos analizó el fenómeno conocido en Perú como barriada (Riofrio, 1982; Matos Mar, 1984; Hall, 1996; Calderón, 1999, 2005).

Actualmente, los procesos por los cuales atraviesan las ciudades latinoamericanas se caracterizan por la agudización de algunos problemas existentes y la aparición de nuevos. Mattos (2002) y Ciccolella (2012) coinciden en indicar que entre los principales cambios se encuentran la configuración reticular del espacio urbano, la cual ha ido acompañada de una agudización de la segregación socio-espacial, mayor fragmentación urbana, así como una mayor expansión urbana. La identificación de estos cambios ha llevado a la búsqueda de nuevas respuestas para hacer frente a sus efectos negativos. Es en ese contexto que surge una especial preocupación por la densidad urbana tanto como elemento de análisis, como valor urbanístico que haría frente a los efectos sociales y ambientales de la dispersión y fragmentación urbanas (Navarro y Ortuño, 2011; Hermida, Hermida, Cabrera y Calle, 2015).

Es decir, como señalan Declève, Ananian, Anaya y Lescieux, (2008), el concepto de densidad es utilizado tanto para analizar el proceso de transformación del territorio (Abramo, 2012; Hermida et al., 2015), como para nombrar una característica positiva fundamental en las propuestas de compacidad urbana (Arbury, 2005; Navarro y Ortuño, 2011). Este trabajo parte de la identificación de la was also associated with this approach; as a result, most of the available studies analyzed a phenomenon that is locally known as barriada (slums) (Riofrio, 1982; Matos Mar, 1984; Hall, 1996; Calderón, 1999, 2005).

Today, the processes experienced by Latin American cities are characterized by the intensification of current social issues and the emergence of new problems. Mattos (2002) and Ciccolella (2012) agree that the reticular configuration of the urban space is one of the major changes identified within this process, which has also involved the intensification of socio-spatial segregation, greater urban fragmentation and urban expansion. The identification of these changes has triggered the search for new answers to address their negative effects. In this context, special attention is given to urban density, both in analytical and urban value terms, as it may contribute to tackle the social and environmental effects of urban dispersion and fragmentation (Navarro and Ortuño, 2011; Hermida, Hermida, Cabrera and Calle, 2015).

According to Declève, Ananian, Anaya and Lescieux (2008), the concept of density is used both to analyze the transformation process of territories (Abramo, 2012; Hermida et al., 2015) and to refer to a critical positive characteristic of proposals on urban compactness (Arbury, 2005; 
preocupación por la densificación como una alternativa de desarrollo urbano, en la literatura especializada y en el Plan de Desarrollo Metropolitano de Lima y Callao 1990-2010 -PLANMET. Y, a partir de ello, se analiza el proceso de densificación habitacional por su potencial rol de motor para los cambios en la estructura urbana (incremento del modelo compacto, incluso en zonas tradicionalmente dispersas), así como en la agudización de los patrones de segregación socio-espacial en el AML, conurbación de las provincias de Lima y Callao (Bensús y Vilela, 2014).

En otras palabras, esta investigación busca ahondar en cómo la planificación de la densificación (o la falta de ella) en un caso de ciudad neoliberal latinoamericana -el AML- se conjuga con las dinámicas del mercado formal de vivienda. Para ello se parte de la hipótesis de que a partir de cambios en los modelos económicos nacionales que se iniciaron -en el caso peruano- en la década del noventa, las gestiones locales han asumido un rol de promotor de la inversión inmobiliaria, dejando de lado la planificación (Molotch, 1976; Harvey, 1989; Fainstein, 2001; Logan \& Molotch, 2007; Alfonso, 2012; Abramo, 2012). Adicionalmente, se sostiene que este modelo de mercantilización de la gestión urbana (Mattos, 2008) ha conllevado, entre sus principales efectos socio-espaciales, una densificación no planificada que refuerza los patrones de segregación residencial.
Navarro and Ortuño, 2011). This paper explores the concerns about densification, as observed in specialized literature and the Metropolitan Development Plan for the Cities of Lima and Callao, 1990-2010 -PLANMET, emerges as a new form of urban development. On this basis, this research analyzes the housing densification process because of its potential to drive changes to the urban structure (expansion of the compact city model, even in traditionally disperse areas), and intensify socio-spatial segregation patterns within the MAL, an urban conurbation that involves the provinces of Lima and Callao (Bensús and Vilela, 2014).

Within the context of a neoliberal Latin American city, MAL, this research seeks to provide further insights into how the planning of densification (or the lack of) goes hand in hand with the dynamics of the formal real estate market. To this end, this paper suggests that changes to nationwide economic models, which started during the 1990s as in the case of Peru, enabled local management initiatives to promote real estate investing, ignoring aspects of planning (Molotch, 1976; Harvey, 1898, Fainstein, 2001; Logan and Molotch, 2007; Alfonso 2012; Abramo, 2012). It is also argued that non-planned densification, and the consequent intensification of residential segregation patterns, is one of the major socio-spatial consequences derived from the commodification of urban management (Mattos, 2008). 
El texto se organiza en cinco partes: i) una revisión conceptual para una economía política de la densificación habitacional; ii) especificaciones metodológicas; iii) el análisis de la mercantilización de la gestión urbana en el AML y el rol de las distintas niveles del Estado; iv) el análisis del proceso de densificación habitacional asociado al mercado formal de vivienda; $y, v)$ las conclusiones de la investigación.

\section{Economía política de la densificación habitacional}

En un trabajo ya clásico en sociología urbana, Logan y Molotch sostienen, siguiendo a Lefebvre (2013), que los lugares y el espacio son productos sociales. Para ser más precisos, la producción de lugares es el resultado de la tensión entre dos tipos de intereses sobre el espacio construido, a saber, como valores de uso o como valores de cambio; tensión en la cual la acción política individual y/o colectiva es trascendental (Logan \& Molotch, 2007).

Este planteamiento es fundamental para entender los procesos de urbanización que, como señala Harvey (2008, p. 24), son el resultado de la búsqueda del capital por generar mayor plusvalor. Es decir, una de las principales formas mediante las
This paper is divided into five sections: i) conceptual review of political economy within the context of housing densification; ii) methodological approach; iii) analysis of the commodification of urban management within the MAL and the role played by different levels of government; iv) analysis of the process of housing densification and its association with the formal real estate market; and v) conclusions.

\section{Political Economy of the Housing Densification}

In a classic work on urban sociology, Logan and Molotch, influenced by Lefebvre (2013), argue that places and space are social products. To be more precise, places are produced as the result of the tension between two types of interests over the built space, which may refer to use value or exchange value; within this tension individual and/or collective political action are essential (Logan and Molotch, 2007).

The above approach is fundamental to understand the urbanization processes which, according to Harvey (2008, p. 24), are the result of the search for capital to obtain greater added value. In other words, capitalism operates largely on the basis of secondary circuits, that is, land and 
que el capitalismo se desarrolla es su circuito secundario, a saber, la inversión en suelo, inmuebles y, en general, la producción del espacio construido (Gotham, 2009). Ahora bien, esta dinámica adquiere características particulares con el proceso de financiarización de la economía global iniciada en la década de 1970 y que comienza a implantarse entre las décadas de 1980 y 1990 en América Latina (Mattos, 2008), pues el negocio inmobiliario ya no sólo se limita a la construcción, sino que implica todo un mercado de especulación financiera (Gotham, 2009).

En este sentido, la relación entre el capital y el territorio cobra especial importancia en estos tiempos. Por un lado, el desarrollo económico reside ahora en la capacidad de gobiernos locales (y nacionales) para atraer inversión a sus territorios, de forma tal que se pueda reinvertir en ellos (Mattos, 2008; Orellana, 2011). Por otro lado, se agudizan las dinámicas de la destrucción creativa del capitalismo pues necesita circular a través de la reconstrucción del espacio urbano, lo cual supone la inversión y construcción en zonas específicas de las ciudades que permitan obtener mayor rentabilidad (Harvey, 2008).

Ahora bien, en ciudades donde el suelo vacante es escaso como en el AML y donde, además, hay una fuerte concentración de actividades económicas, la construcción en densidad se hace más rentable. Como señala Jaramillo (2003), la construcción en real estate investment and, generally speaking, the production of built spaces (Gotham, 2009). However, this dynamic took on particular characteristics with the financialization of global economics, a process that began at the beginning of the 1970s and then implemented in Latin America during the 1980s and 1990s (Mattos, 2008). In this context, the real estate business was not only restricted to the building activity, but encompassed an entire speculative market (Gotham, 2009).

In this sense, the relationship between capital and territory becomes significant. On the one hand, economic development depends on the ability of local (and national) governments to attract investors for reinvestment purposes (Mattos, 2008; Orellana, 2001). On the other hand, the creative destruction dynamics of capitalism become exacerbated since there is a need to reconstruct the urban space; this means investing and implementing construction projects in specific areas of the city in order to achieve higher returns (Harvey, 2008).

However, cities with strong economic activity and a scarcity of available land for construction, as in the case of the MAL, high density construction offers greater returns. According to Jaramillo (2003), high-rise construction becomes profitable when people are willing and able to purchase smaller properties (when compared to 
altura es rentable cuando existe gente dispuesta y capaz de pagar por viviendas de menor tamaño (en comparación con muchas viviendas unifamiliares), a cambio de estar más cerca de nodos de empleo, ocio, educación, etc. Esto explica en parte la tendencia del mercado inmobiliario formal a concentrar la oferta en viviendas multifamiliares en el AML, lo que es equivalente a un proceso de densificación habitacional. Asimismo, se confirma la relevancia del concepto de densidad para el análisis de transformaciones del territorio metropolitano.

La discusión sobre la densidad de las ciudades no es un fenómeno nuevo, ha sido un tema que ha preocupado tanto a gestores urbanos como a académicos durante mucho tiempo, en ocasiones preocupados por altas densidades y, en otras, por las bajas densidades en centros o suburbios (Angel, Parent, Civco \& Blei, 2010). En el plano académico y proyectual, las propuestas de construcción en densidad contemporáneas pueden rastrearse hasta el Congreso Internacional de Arquitectura Moderna -CIAM, cuyo representante más conocido fue Le Corbusier (Navarro y Ortuño, 2011). Asimismo, Hermida et al. (2015, p. 28) identifican un conjunto de documentos que, hacia finales del siglo XX, habrían guiado la discusión sobre nuevas formas de producir ciudad; entre esos documentos

3 La propuesta de Le Corbusier, llamada "La ciudad radiante" incluía grandes torres para la vivienda y grandes autopistas, por la creciente importancia del automóvil como medio de transporte en la ciudad (Hall, 1996). many single-family homes) if they are located near workplaces, leisure areas, education establishments, etc. This partly explains why the formal real estate market tends to concentrate the supply of multifamily homes within the MAL; the latter may be considered as an equivalent to a housing densification process. Likewise, this fact confirms the importance of the concept of density within the context of the analysis of the transformations that take place in metropolitan territories.

The debate on the density of cities is not a recent phenomenon; this topic has sparked concern among urban planners and scholars for a long time, at times discussions focus on high density, at others on the low density of urban or suburban areas (Angel, Parent, Civco and Blei, 2010). In academic and project terms, contemporary density building proposals date back to the International Congress of Modern Architecture -CIAM, whose most prominent figure was Le Corbusier (Navarro and Ortuño, 2011) ${ }^{3}$. Likewise, Hermida et al. (2015, p. 28) identified a series of documents that, by the end of the 20th century, guided the discussion on city production methods. These texts included the Brundtland Report (1987) and the Charter of the

3 The proposal made by Le Corbusier, entitled "Radiant City", included large towers intended for habitation purposes and ample highways aimed to tackle the growing importance of cars as a means to travel within the city (Hall, 1996). 
se encuentran el Informe Brundtland de 1987 y la Carta del Nuevo Urbanismo de 1993. Entre las principales preocupaciones de estos documentos están el desarrollo urbano sostenible y el aumento de la densidad urbana como una característica fundamental para conseguirlo.

En la actualidad, gran parte del debate sobre la densidad está asociado al modelo de ciudad compacta como solución a los problemas que supone la dispersión urbana. Esto supone una propuesta de desarrollo sostenible a través de altas densidades, usos mixtos de predios, habitabilidad, acceso a servicios y transporte sostenible (Arbury, 2005; Hermida et al., 2015). Así, la compacidad supondría menores distancias de desplazamiento para acceder a servicios o ir a trabajar y dependería de una mayor densificación habitacional. Sin embargo, como demuestra el trabajo de Cervero (1998), la vida en multifamiliares no implica necesariamente una mejor habitabilidad o satisfacción con la calidad de vida.

En tanto indicador, la densidad suele hacer referencia a la relación entre número de habitantes y un área determinada, sin embargo este indicador es más complejo. El coeficiente puede medirse según el área total de una ciudad de acuerdo a los límites político-administrativos o al área urbana, incluso el nivel de precisión puede llegar a utilizar como dato el área construida para vivienda (Angel et al., 2010; Clark \& Moir, 2015). La densidad puede
New Urbanism (1993), which carefully address issues such as sustainable urban development and the increase in urban density -the latter regarded as a fundamental characteristic that would enable the achievement of such a goal.

Today, much of the discussion on the density issue is associated with the compact city model, which may provide the solution to the problems derived from urban dispersion. This is because this model offers a sustainable development proposal based on the creation of high densities, mixed use of land, habitability and access to services and sustainable transport (Arbury, 2005; Hermida et al., 2015). In this way, compactness would entail travelling shorter distances to reach the workplace or service providers and it would depend on the generation of greater housing density. However, as the work of Cervero (1998) suggests, living in multifamily homes does not necessarily involve better habitability conditions or proper quality of life.

In value terms, density refers to the relationship between the number of inhabitants and a given area; however, this is a complex indicator. This coefficient is measured by taking the total area of a city according to political-administrative limits or its urban area; given its precision level, this instrument can even use data associated with the constructed area for housing purposes (Angel et al., 2010; Clark and Moir, 2015). Density may 
hacer referencia no solo a la población residente, sino incluir a la población flotante en zonas de alta concentración de empleo (Declève et al., 2008). Un tipo particular de densidad, relevante para este trabajo, se vincula a la densificación habitacional, entendida como el uso intensivo del suelo a través de la construcción de departamentos.

Clark y Moir (2015, p. 15) identifican dos tipos de fenómenos que impulsan el aumento de la densidad: impulsores primarios y secundarios. Los primarios son el crecimiento poblacional, la re-urbanización de negocios y empleo, y preocupaciones referidas a la sostenibilidad. Mientras que los impulsores secundarios se refieren a características de la estructura urbana como la localización de infraestructura, las tendencias de inversión del capital (aumento de inversión en proyectos inmobiliarios), las nuevas tendencias en diseño arquitectónico y los avances en tecnología vinculados al diseño de edificios. Estos mismos autores hacen hincapié en la importancia de planificar la densificación y que esta sea complementada con espacios públicos de calidad, servicios y otras características que, de no tomarse en cuenta, limitarían la posibilidad de otorgar buenas condiciones de vida a los residentes (Clark \& Moir, 2015, p. 13-15).

En otras palabras, el proceso de densificación es resultado de lo que Logan y Molotch (2007) han denominado como el conflicto entre valor de uso (la demanda de vivienda) y valor de cambio not only refer to resident populations, but also to floating populations concentrated in employment areas (Declève et al., 2008). A specific type of density, which is of great value for the purposes of this research, is related to housing density, which is understood as the intensive use of land for the construction of high-rise buildings.

Clark and Moir (2015, p. 15) identify two types of phenomena that increase density: primary and secondary drivers. Primary drivers are associated with population growth, business and employment redevelopment concerns that refer to sustainability. Secondary drivers refer to characteristics of the urban structure such as location of infrastructure, capital investment trends (increased investment in real estate projects), new architectural design trends and technology advances in the design of buildings. These authors stress the importance of density planning and the creation of quality public spaces, services and other features that, if ignored, may limit the possibility of providing proper living conditions to residents (Clark and Moir, 2015, p. 13-15).

In other words, the densification process is the result of what Logan and Molotch (2007) refer to as the conflict between use value (housing demand) and exchange value (growing private interest over real estate investment). The specific dynamics of this tension are influenced by the 
(interés privado creciente en invertir en inmuebles). Y, las dinámicas específicas de esta tensión están influenciadas por las características propias de la estructura urbana de cada ciudad y por la aplicación de avances en tecnología, así como los cambios en la estructura laboral y sus manifestaciones espaciales.

\section{Nota metodológica}

La metodología empleada en este trabajo fue de carácter mixto y se dividió en dos etapas. La primera referida al análisis de información secundaria censal y del Registro Nacional de Municipalidades (RENAMU) para identificar los planes con los que contaban los 49 distritos del AML en el periodo estudiado. La segunda etapa implicó un trabajo cualitativo complementario de entrevistas a actores clave y, paralelamente, se analizó la oferta formal de departamentos.

Específicamente, a partir de información censal se georreferenció el lugar de residencia por estratos socioeconómicos y la densidad poblacional. También, se generó una base de datos a partir de characteristics of the urban space of each city, the implementation of technology advances and changes in the employment structure and its related spatial manifestations.

\section{Methodology}

This research takes a mixed method approach and is divided into two stages. The first stage analyzes secondary census information and data released by the National Municipal Registry (RENAMU); the aim of this section is to identify the plans of the 49 districts located within the MAL over the period under review. The second stage involves complementary qualitative work through interviews with key actors and the analysis of the formal supply of apartments.

More specifically, census information was used to georeference the place of residence according to socioeconomic level and population density. This research generated a database from the annual real estate studies released by the National Chamber of Construction (CAPECO) ${ }^{4}$, which enabled analysis of the number of housing

4 This research uses data released by the annual publication entitled "The Urban Building Market in Metropolitan Lima and Callao" over the period 2000 to 2014. 
los estudios del mercado inmobiliario que realiza anualmente la Cámara Peruana de la Construcción $(\mathrm{CAPECO})^{4}$, que permitió analizar la cantidad de unidades construidas entre 2000 y 2014 por distrito y por gran zona del AML. Además, se analizó la oferta de departamentos según el estrato socioeconómico al cual estaba dirigido. Por último, se realizaron entrevistas a funcionarios encargados de la gestión urbana de distintos distritos del AML y a representantes de empresas inmobiliarias.

La investigación se centra en el análisis de la oferta de departamentos pues, como señalan Bensús y Vilela (2014), es la actividad más importante en términos absolutos y relativos del mercado inmobiliario formal y, además, la que supone los cambios más importantes de la morfología urbana -específicamente, para la densificación habitacional. Además, es importante señalar que, en un primer momento, se utiliza el coeficiente de densidad poblacional en base al cálculo de la relación entre población y área urbanizada por distrito del AML. Y, en un segundo momento, se analizan las dinámicas de la oferta de departamentos como una variable de análisis de la densificación habitacional. Asimismo, incluir entrevistas a funcionarios y representantes de empresas inmobiliarias ayudó al análisis de las tensiones entre dichos actores y units built over the period 2000 to 2014, both at district and larger spatial levels within the MAL. Likewise, this paper analyzed the supply of apartments according to socioeconomic group. Lastly, different interviews were conducted with urban management officials from different districts within the MAL and representatives of real estate companies.

This research focuses on the supply of apartments since, as Bensús and Vilela (2014) suggest, this is the most important activity in absolute and relative terms associated with the formal real estate market and also because it involves greater changes to urban morphology in housing density terms. Likewise, it is important to point out that this paper uses the housing density coefficient, which is based on the relationship between the population and the built areas of each district within the MAL. This paper also explores the dynamics driving the supply of apartments as they provide new approaches to analyze the housing density phenomenon. In addition, the inclusion of interviews with officials and representatives of real estate companies enabled the analysis of the tensions between these actors and their role in the densification process that is taking place within the MAL.

4 Se usó la publicación anual “El mercado de edificaciones urbanas en Lima Metropolitana y el Callao", entre el 2000 y 2014. 
la forma de proceder de cada uno en el proceso de densificación del AML.

\section{Estado y mercantilización de la gestión urbana en el AML}

En el año 1992, la Municipalidad Metropolitana de Lima -MML- publicó el Plan de Desarrollo Metropolitano de Lima-Callao 1990-2010, PLANMET. Dicho documento contenía modificaciones añadidas mediantes acuerdos del Concejo Metropolitano de Lima en 1991 a las versiones originales trabajadas desde 1989 (Municipalidad Metropolitana de Lima, 1992). La vigencia de dicho documento de planificación se extendió hasta el 2014, pues no se ha aprobado un nuevo Plan.

Uno de los objetivos planteados en dicho documento es el uso intensivo del suelo del área central de la metrópoli (tabla 1) para el uso residencial, ya sea a través de subdivisión de lotes o de densificación habitacional (Municipalidad Metropolitana de Lima, 1992, p. 111). Sin embargo, esta propuesta no incluye una referencia a cómo se daría este proceso ni a su vinculación con una oferta de vivienda social. Lo que sí se plantea es la generación de estímulos y modificaciones normativas para participación privada en la planificación y gestión urbanas (Municipalidad Metropolitana de Lima, 1992, p. 119). Es decir, la planificación plantea sólo la idea de densificar y obvia las implicancias

\section{The State and the Commodification of Urban Management within the MAL}

In 1992, the Metropolitan Municipality of Lima (MML) released the Metropolitan Development Plan for the Cities of Lima and Callao, 19902010, PLANMET. Approved in 1991 by the Lima Metropolitan Council, this document contained a series of amendments to the original 1989 documents (Metropolitan Municipality of Lima, 1992). The validity of this document was extended until 2014 as no new plan has yet been approved.

One of the objectives of this document addresses the intensive use of land in the central area of the metropolis (Table 1) for residential purposes, either through the subdivision of land or housing densification (Municipalidad Metropolitana de Lima, 1992, p. 111). However, this proposal does not explain the characteristics of this process or its relation to the housing supply. What it proposes, instead, is the generation of incentives and regulatory modifications to favor the participation of private parties in urban planning and management activities (Municipalidad Metropolitana de Lima, 1992, p. 119). In other words, planning initiatives are governed by densification, ignoring the social consequences of this process and housing demands at metropolitan level. 
sociales de este proceso y la demanda metropolitana de vivienda.

Ahora bien, la densificación es un proceso que no se habría iniciado sin políticas diseñadas e implementadas a las escala del Gobierno Nacional. Entre la década de 1990 e inicios de los 2000, muchas de estas políticas propiciaron cambios importantes en la gestión urbana de las ciudades peruanas. El primero consistió en la implementación del Plan de Ajuste Estructural, que implicó una serie de reformas entre las que resalta la reforma fiscal, pues supuso la reducción del número de impuestos, la revisión de tasas y el sinceramiento de los valores de predios (Pereyra, 2004; Gonzales, Del Solar y Del Pozo, 2011). Uno de los efectos de esta reforma fue que aumentaron los recursos de los municipios distritales para gastos en limpieza de calles y mantenimiento de parques e infraestructura (Gonzales et al., 2011, p. 156, 171).

Un segundo proceso está relacionado con las reformas de descentralización que comenzaron a implementarse en el gobierno del presidente Alejandro Toledo entre 2002 y 20065. Estos cambios se dieron en las dimensiones fiscal, administrativa y económica. En otras palabras, los gobiernos locales comenzaron a recaudar mayores ingresos propios,

5 En este mismo gobierno se reactivó el Ministerio de Vivienda, Construcción y Saneamiento, ente encargado a nivel del gobierno nacional, del diseño de políticas en vivienda y planificación urbana.
Densification is a process that could have not been achieved without the generation of policies designed and implemented at National Government level. From the 1990s to the 2000s, many of these policies triggered major changes in the urban management of Peruvian cities. The first of these changes consisted in the implementation of the Structural Adjustment Plan, which introduced a series of reforms, chief among them the fiscal reform as it reduced the number of taxes, revised rates and adjusted the value of land (Pereyra, 2004; Gonzales, Del Solar and Del Pozo, 2011). A major impact of this reform was the greater allocation of resources for district municipalities, which should be used for street cleaning purposes and to maintain parks and infrastructure (Gonzales et al., 2011, p. 156, 171).

The second process is related to the decentralization reforms implemented by the Toledo administration from 2000 to $2006^{5}$. These changes took place at fiscal, administrative and economic level. In other words, local governments collected more revenues, took on new powers and received more funds from the National Government. Some of the negative or unexpected consequences of this restructuration program are the overlapping of functions among the different

5 This administration revitalized the Ministry of Housing, Construction and Sanitation, which is in charge of designing housing and urban planning policies at national level. 
asumieron nuevas competencias y se incrementaron los montos de las transferencias de fondos desde el Gobierno Nacional. Entre los efectos perversos o no esperados de esta reestructuración se encuentra la superposición de funciones entre niveles de gobierno y la competencia interdistrital por atraer inversión inmobiliaria a su territorio.

En ese sentido, el AML está conformada por 50 gobiernos locales, 43 correspondientes a los distritos de la Provincia de Lima y siete a Callao ${ }^{6}$. Además, cada provincia cuenta con un gobierno autónomo de escala y atribuciones regionales. Entre las principales atribuciones a escala provincial está el mantenimiento de grandes vías, aprobación de cambios de zonificación, otorgación de permisos para rutas de transporte público, así como la planificación a escala metropolitana. Mientras que los gobiernos locales tienen atribuciones en la escala distrital.

Una tercera política que influyó en las nuevas dinámicas del mercado inmobiliario y de la gestión urbana en el AML fue la creación del Fondo Mi Vivienda -FMV en 1997, que comenzó a otorgar préstamos en 1999. Esta iniciativa estatal busca facilitar el acceso a vivienda para las clases medias, y es conducida por actores privados con la participación de bancos que administran el dinero

6 En el 2014, una de las barriadas de mayor extensión, Mi Perú, localizada en el distrito de Ventanilla en la provincia del Callao, se convirtió en distrito independiente mediante la Ley 30197. governmental levels and the competition among districts to attract real estate investment.

In this sense, the MAL consists of 50 local governments, 43 of them located in the Province of Lima and the remaining seven located in Callao ${ }^{6}$. Likewise, each province has a local government that operates at regional level. Some of the main provincial-related powers are associated with the maintenance of roads, approval of zoning modifications, granting of permits for public transport routes and metropolitan planning. Local governments have powers at district level.

The third policy that influenced the new real estate and urban management dynamics within the MAL was the creation of the Mi Vivienda Fund -FMV- in 1997; such an entity began providing home loans in 1999. This state-led initiative, controlled by private actors and banking institutions that administer money and determine the eligibility of credit applicants, aims to provide better access to housing for the middle class (Calderón, 2009). In this way, real estate companies take less risk when investing and may even submit proposals to the government. The latter element is of great importance since, according to this logic, the state has transferred public lands for the construction of multifamily

6 In 2014, through Act No. 30197, Mi Perú, one of the largest slums located in the district of Ventanilla, Callao, became an independent district. 
TABLA 1. DISTRITOS DEL AML POR ZONA.

TABLE 1. DISTRICTS LOCATED WITHIN THE MAL, DISTRIBUTED BY AREA.

\begin{tabular}{|c|c|}
\hline $\begin{array}{l}\text { Gran zona de } \\
\text { Lima }\end{array}$ & Distritos \\
\hline Lima Centro & $\begin{array}{l}\text { Barranco, Miraflores, Surquillo, San Isidro, Magdalena del Mar, San Borja, Lince, Santiago de } \\
\text { Surco, Pueblo Libre, Jesús María, San Luis, San Miguel, La Victoria, Lima Cercado, Breña, y Rímac }\end{array}$ \\
\hline Callao* & Callao, La Punta, Ventanilla, Carmen de la Legua, La Perla y Bellavista \\
\hline Lima Norte & $\begin{array}{l}\text { Independencia, San Martín de Porres, Los Olivos, Comas, Puente Piedra, Ancón, Santa Rosa, } \\
\text { Carabayllo }\end{array}$ \\
\hline Lima Este & $\begin{array}{l}\text { La Molina, Santa Anita, El Agustino, Santa Anita, Ate, Lurigancho, Chaclacayo y San Juan de } \\
\text { Lurigancho }\end{array}$ \\
\hline Lima Sur & $\begin{array}{l}\text { Pucusana, Santa María del Mar, Chorrillos, Lurín, Villa El Salvador, Villa María del Triunfo, San } \\
\text { Bartolo, Punta Negra, Punta Hermosa, Pachacamac y San Juan de Miraflores }\end{array}$ \\
\hline
\end{tabular}

* En 2014, mediante la Ley 30197, se creó el distrito de Mi Perú, escisión del distrito de Ventanilla, de la Provincia Constitucional del Callao. Este trabajo presenta información solo de los 49 distritos existentes previos a dicha modificación.

Fuente: elaboración propia

* In 2014, the Mi Perú district was created by Act No. 30197; this territory was split from the Ventanilla district, Constitutional Province of Callao. This paper presents information of the 49 districts established before this amendment.

Source: elaborated by the author

y sirven como entidades calificadoras para quienes acceden a créditos (Calderón, 2009). De esta manera las empresas inmobiliarias tienen mayor seguridad para sus inversiones e, incluso, pueden ser las que propongan proyectos al gobierno. Este último elemento es relevante, pues bajo esta lógica el Estado ha desafectado terreno de su propiedad homes, thus facilitating zoning changes and relaxing construction patterns.

In addition, the pressure exerted by real estate companies, banks and the media led to the implementation of tax exemptions for dwellings whose value is less than $\$ 30,000$. In addition, 
para la construcción de multifamiliares, facilitado cambios de zonificación y flexibilizado parámetros de construcción.

Adicionalmente, a partir de presión de las empresas inmobiliarias, bancos y medios de comunicación, se implementó la exoneración tributaria para vivienda de valor menor a $\$ 30,000$. A esto, se sumó el costo del suelo en los impuestos para compra de viviendas, lo que permitió el incremento del costo de los departamentos producidos (Calderón, 2009). Estos cambios no pararon ahí, sino que diferentes modificaciones a leyes y promulgación de otras nuevas, enfocadas en estimular la inversión privada, también resultaron en flexibilización de normas de construcción. En ese sentido, toda ley enfocada en incentivar el crecimiento económico implicó modificaciones en la ley nro. 29090, Ley de regulación de habilitaciones urbanas y edificaciones. Como consecuencia, el negocio de la construcción de vivienda se hizo rentable incluso para aquellos departamentos que no están comprendidos en el FMV.

Estas reformas tuvieron consecuencias claras para la gestión urbana a escala metropolitana y distrital. A pesar de que el sistema de asignación presupuestal del Estado peruano exige contar con diversos planes para acceder a dichos recursos, no muchos gobiernos locales cuentan con ellos. Así, pudo identificarse que entre 2004 y 2013 (figura 1), salvo el Presupuesto Participativo -PP y los Planes de Desarrollo Concertado -PDC, otros planes no taxes on the purchase of housing included the cost of land, thus increasing the value of new apartments (Calderón, 2009). Likewise, different amendments to existing laws and the adoption of new regulations aimed to promote private investment have also led to the relaxation of building standards. In this sense, all laws intended to boost economic growth meant the amendment to Act No. 29090 on the Regulation of Urban Development and Buildings. As a result, housing construction became a profitable business, even in the case of apartments that were not included in the FMV.

These reforms had visible consequences for urban management, both at metropolitan and district level. Despite the Peruvian resource allocation system requires different plans to access these funds, few local governments enjoy such a benefit. This research identified that two -the Participatory Budget (PP) and the Concerted Development Plans (PDC) - out of a series of different plans were regularly used by local administrations over the period 2004 to 2013 (Figure 1). In all other cases, these plans were used by less than half of districts, with the exception of the Environmental Management Plans (63.27 percent).

Disregarding management documents that are closely related to the receipt of funds from the central government (PP and PDC), the above clearly illustrates how urban management is 
suelen ser utilizados por las gestiones locales. En todos los demás casos no se llega ni a la mitad de distritos, salvo por el aumento de municipios con Planes de Gestión Ambiental en 2012 (63,27\%).

Este es un ejemplo de cómo, salvo documentos de gestión que están estrechamente ligados a la recepción de fondos por el gobierno central (PP y PDC), la gestión urbana ha dejado de utilizar herramientas de planificación. Esta tendencia se confirmó en entrevistas a funcionarios de gestión urbana, quienes señalan que los planes implicaban un costo monetario y de tiempo que preferían evitar. Por ello, mencionaron que prefieren utilizar normativa específica de edificación o incluso acuerdos de palabra con los responsables de las inmobiliarias, esto es lo que Fainstein (2001) llama el paso de la planificación al deal-making en la gestión urbana.

Las entrevistas a funcionarios también permitieron identificar que está difundida entre los gestores la idea de que atraer inversión inmobiliaria debe ser uno de sus objetivos principales, pues de esa forma llegaría población de estratos medios y altos que, según una gerente de Desarrollo Urbano "sí pagan impuestos". Es decir, el nuevo régimen fiscal y de recaudación de recursos propios exige a los gobiernos locales motivar inversión y tener mayor seguridad sobre el pago de tributos, lo cual asocian a estratos más altos. Para ello, muchos municipios están dispuestos a implementar planes de no longer using planning tools. Such a tendency was confirmed by the interviews with urban management officials, who preferred to avoid the monetary and time costs of these plans. They also were inclined to use specific building regulations or even reach oral agreements with real estate representatives; the latter is what Fainstein (2001) refers to the transition from planning to dealmaking within an urban management context.

The interviews with officials were also useful to identify a widespread idea among planners that attracting real estate investment is a primary objective. This is because such an action would involve the arrival of individuals from middle or upper class backgrounds who, according to an Urban Development manager, are able to "pay taxes". In other words, the new fiscal system and the collection of their own resources require local governments to promote investment and properly secure the payment of taxes, the latter being regarded as a characteristic associated with the upper class. To this effect, an important number of municipalities are able to implement urban renewal plans or zoning changes in order to turn their districts into more attractive spaces.

In many of these cases, officials act as intermediaries among tenants, property owners and real estate investors. An example of this is the case of an official who convinced a group of poor residents who rented a residence in the district she worked in to accept turning a house 
FIGURA 1. MUNICIPIOS DEL AML QUE CUENTAN CON HERRAMIENTAS DE GESTIÓN 2004-2013.

FIGURE 1. MUNICIPALITIES WITHIN THE MAL PROVIDED WITH MANAGEMENT TO0LS, 2004-2013.

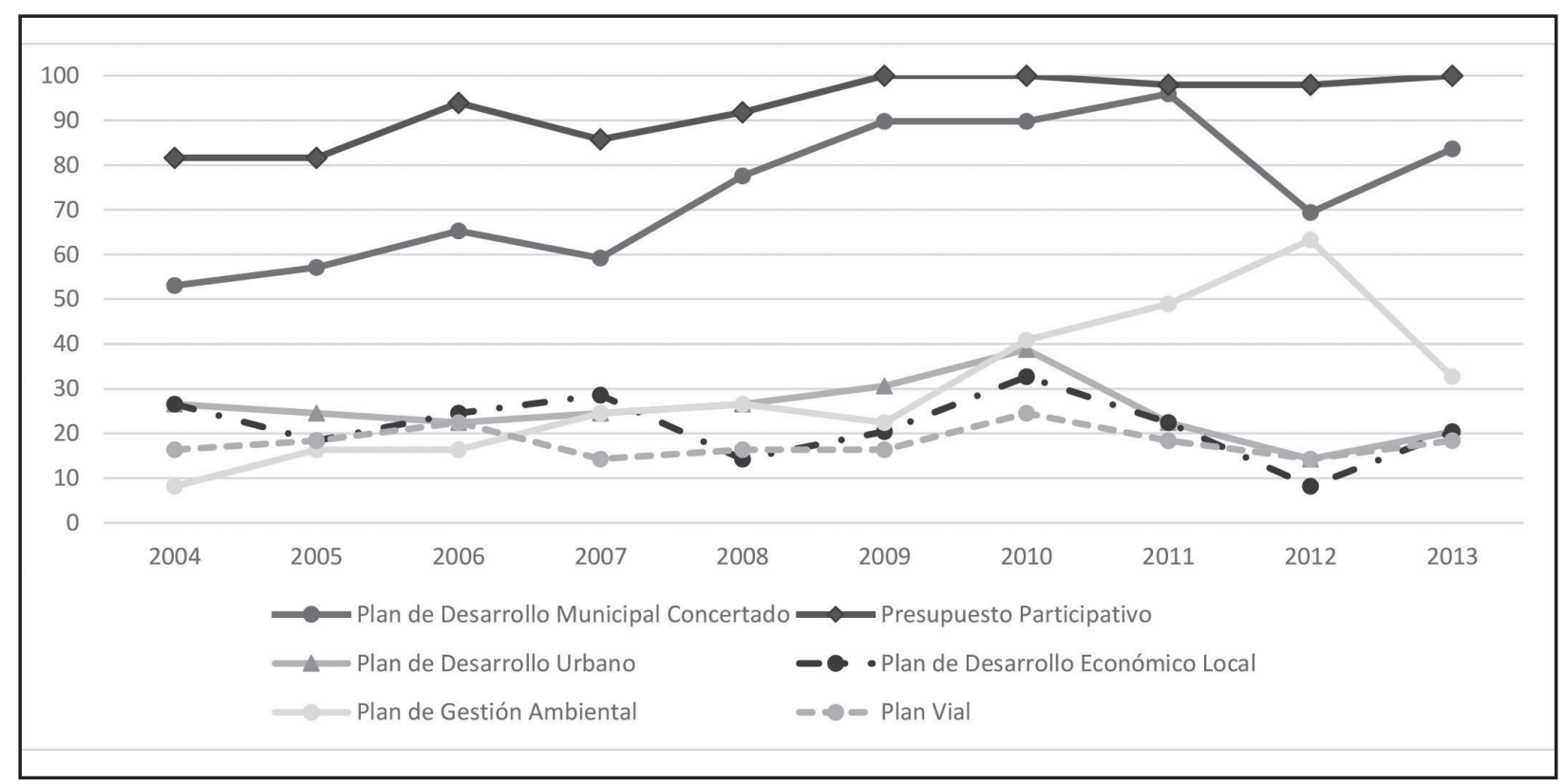

Fuente: INEI, RENAMU. Elaboración propia.

Source: INEI, RENAMU. Elaborated by the author. 
renovación urbana o cambios de zonificación que hagan más atractivos a sus distritos.

En muchos de estos casos, los funcionarios hacen las veces de intermediarios entre inquilinos, propietarios e inversores inmobiliarios. Un ejemplo de esto último es el caso de una funcionaria que intermedió para convencer a residentes pobres que alquilaban una vivienda en su distrito de aceptar dejar una vivienda tugurizada, para que pueda ser vendida. Estas situaciones son un ejemplo de lo que Roy (2009) describe como la manera en la cual la informalidad es el modo de planificación incluso a través del Estado.

Es importante precisar que las relaciones descritas anteriormente no son ajenas al conflicto entre los distintos actores involucrados. Como mencionan Logan y Molotch (2007), en la producción del espacio se manifiesta el conflicto entre actores que buscan valores de uso y otros que buscan valores de cambio. Entonces, existen incomodidades en la escala local de gobierno por disposiciones en las into an inhabitable space in order to force the sale of such a property. These situations are examples of what Roy (2009) describes as the way informality becomes a planning method, even with the state acting as an intermediary.

It is important to stress that the above relationships are not alien to the conflicts among the different actors involved in this issue. As Logan and Molotch (2007) point out, the production of space is the scenario were conflicts between actors seeking for use and exchange values, respectively, takes place. Therefore, there are unbalances at the local government scale as the result of orders generated from metropolitan ${ }^{7}$ or national spheres ${ }^{8}$, especially when it comes to those provisions aimed to reduce assessment times and increasing inspection duties at little budgetary cost.

Likewise, negotiations between representatives of real estate companies and municipal officials have not always been friendly and, in some cases, have resulted in the halting of building

7 An example of this was Ordinance No. 1607, which required local governments to receive, analyze and respond zoning changing requests within 75 days. Likewise, this order included the implementation of a non-binding neighbourhood consultation process that should be supervised by local governments before submitting proposals to the MML.

8 Act No. 30056, 2013 and Draft Act No. 03690, 2014, submitted by the Executive, aimed to promote investment and the relaxation of building standards through the amendment of Act No. 29090. 
escalas metropolitana ${ }^{7}$ o nacional ${ }^{8}$, en especial las que reducen tiempos de evaluación y aumentan el trabajo de fiscalización de los primeros sin otorgarles mayores recursos.

De igual manera, las negociaciones entre los representantes de inmobiliarias y los funcionarios municipales no siempre son cordiales y, en algunos casos, han supuesto paralizaciones de obras. Sobre esto último, los distritos con mayor población de estratos altos y que tienen mayor demanda de vivienda suelen tener mejores condiciones de negociación (Bensús y Vilela, 2014). Otro conflicto usual es entre vecinos residentes y empresas inmobiliarias por cómo afectan las obras nuevas a la infraestructura de las viviendas ya existentes, relación en la que la municipalidad hace las veces de conciliadora.

En este contexto, el Estado, en sus diversas escalas pero principalmente a través de los gobiernos locales, toma un rol activo en el desarrollo de la inversión inmobiliaria. Este rol les ha supuesto asumir funciones de mediadores

7 Un ejemplo es la Ordenanza 1607 que estipulaba que los gobiernos locales serían los encargados de recibir pedidos de cambios de zonificación y debían analizar y responder las solicitudes en un plazo máximo de 75 días. Además, incluía un proceso de consulta vecinal no vinculante a cargo del mismo gobierno distrital, antes de derivar el expediente a la MML.

8 La ley 30056 en 2013 y el proyecto de ley 03690-2014, presentado por el poder ejecutivo, buscaban incentivar la inversión, incluyendo la flexibilización de normas de construcción a través de la modificación de la ley 29090. construction. As regards the latter, districts with higher concentration of upper class groups, who have also greater housing demands, enjoy better negotiation conditions (Bensús and Vilela, 2014). Another common issue is the conflict between resident neighbors and real estate companies over the construction of new buildings and its consequences on the infrastructure of already existing dwellings; in this case, the municipality acts as a conciliator between both groups.

In this context, the state, through its different levels but especially through local governments, takes on an active role in the development of real estate investment. This involves assuming a mediating or conciliating role, thus relegating planning functions to the background. Current guidelines, zoning initiatives and the different management instruments are more focused on promoting, controlling or adapting themselves to real estate investment than on the construction of cities or meeting housing demands at metropolitan level. 
o conciliadores y ha relegado la planificación a un segundo plano. Las normas, la zonificación y los diversos instrumentos de gestión se enfocan más en adaptarse, fomentar o controlar la inversión inmobiliaria y no en la construcción de ciudad, ni en las demandas de vivienda a escala metropolitana.

\section{La densificación (no) planificada 2000-2014}

Al analizar la densidad por área urbana de cada distrito del AML en 1993 y 2007, se puede apreciar que la zona central, a pesar de contener mayor cantidad de distritos no presenta una densidad tan alta, salvo por los distritos de Rímac, Lince, La Victoria y Breña. Según datos del Instituto Nacional de Estadística e Informática (2007), el tipo de vivienda en departamento estaba sobre el 20\% todos los distritos del área central, salvo el Rímac 9 . Curiosamente, este último distrito es uno de los que presenta mayor densidad poblacional dentro de dicha zona.

En otras palabras, la densidad poblacional no se correspondía necesariamente con la densidad habitacional. Además, estos datos coinciden con la

9 Las cifras se encontraban entre el $40 \%$ y el $70 \%$ en los distritos de Jesús María, Lince, Miraflores, San Borja, San Isidro y Santiago de Surco (Instituto Nacional de Estadística e Informática, 2007).

\section{(Non)Planned Densification, 2000-2014}

The density analysis of each district within the MAL, divided by urban area, over the period 1993 to 2007 reveals that the central area, despite having the larger number of districts, does not show high density rates, with the exception of the districts of Rimac, Lince, La Victoria and Breña. According to data released by the National Statistics and Information Institute (2007), apartments accounted for more than 20 percent of housing units in all districts within the central area, with the exception of the district of Rimac ${ }^{9}$. Strangely enough, the latter district shows the higher population density rates within the area under review.

In other words, population density is not necessarily associated with housing density. Likewise, these data are in line with the morphological dualism hypothesis proposed by Abramo (2012): the central area is governed by the compact city model and other areas are defined by the dispersed city model. The latter is related to the fact that most of the urban areas located outside the center of the metropolis have their roots in former slums, which tend to replicate the single-family housing pattern.

9 Figures ranged from 40 to 70 percent in the districts of Jesús María, Lince, Miraflores, San Borja, San Isidro and Santiago de Surco (National Statistics and Information Institute, 2007). 
hipótesis de Abramo (2012) de un dualismo morfológico: en el área central el modelo compacto está más presente, mientras que en otras áreas el modelo difuso prima. Esto último tiene relación con el hecho de que gran parte de la urbanización de áreas fuera del centro de la metrópoli tiene su origen en barriadas, las cuales suelen seguir el modelo de vivienda unifamiliar.

A esto se suma que la población de mayores recursos se ubica en la zona central de la metrópoli (figura 3). Los trabajos de Pereyra (2006) y Fernández de Córdova, Moschella y Bogdanovich (2011) han demostrado que los distritos de dicha zona son más homogéneos; ahí vive mayor población de estratos socioeconómicos medios y altos. Entonces, si bien es de esperar que los distritos que albergan a los estratos socioeconómicos más altos no tengan una población residente tan alta, llama la atención que la densidad del área central sea tan baja pues en esta zona se concentra la mayor cantidad de servicios y empleos de la metrópoli (Chion, 2002; Gonzáles y Del Pozo, 2012).

En este contexto, surge la pregunta sobre cómo es que se ha organizado la oferta inmobiliaria formal en los últimos quince años, teniendo en cuenta que a partir de 2006 habría iniciado un "boom" en el sector (Calderón, 2015). La relevancia de analizar la oferta de departamentos no tiene sólo una justificación teórica, sino que responde al tipo
Additionally, higher-income groups are distributed within the central area of the metropolis (Figure 3). Research conducted by Pereyra (2006) and Fernández de Córdova, Moschella and Bogdanovich (2011) show that central districts are homogeneous in nature as they are home to most of the population from middle and upper class backgrounds. Therefore, while it is understood that these districts do not show high population rates, it is interesting to observe the lower density of the central area as the majority of jobs and services are concentrated in this part of the metropolis (Chion, 2002; Gonzáles and Del Pozo, 2012).

In this context, the question arises as to the organization of the formal housing supply over the last 15 years, considering the real estate boom that began in 2006 (Calderón, 2015). The importance of analyzing the provision of apartments is not only based on theoretical grounds as they also account for the largest supply of housing units within the real estate market. In absolute terms, the housing supply has been experiencing a gradual increase (it shrank only over a 4-year period to immediately recover the following year). In relative terms, the supply of apartments accounts for more than 80 percent of dwellings, with the exception of the years 2003 (71.3 percent) and 2004 (72.7 percent). The latter reveals a tendency associated with the intense use of land, which refers to the densification 
FIGURA 2. DENSIDAD URBANA POR DISTRITO Y GRANDES ZONAS DEL AML 1993 Y 2007.

FIGURE 2. URBAN DENSITY DISTRIBUTED BY DISTRICT AND GREATER AREAS WITHIN THE MAL, 1993 AND 2007.

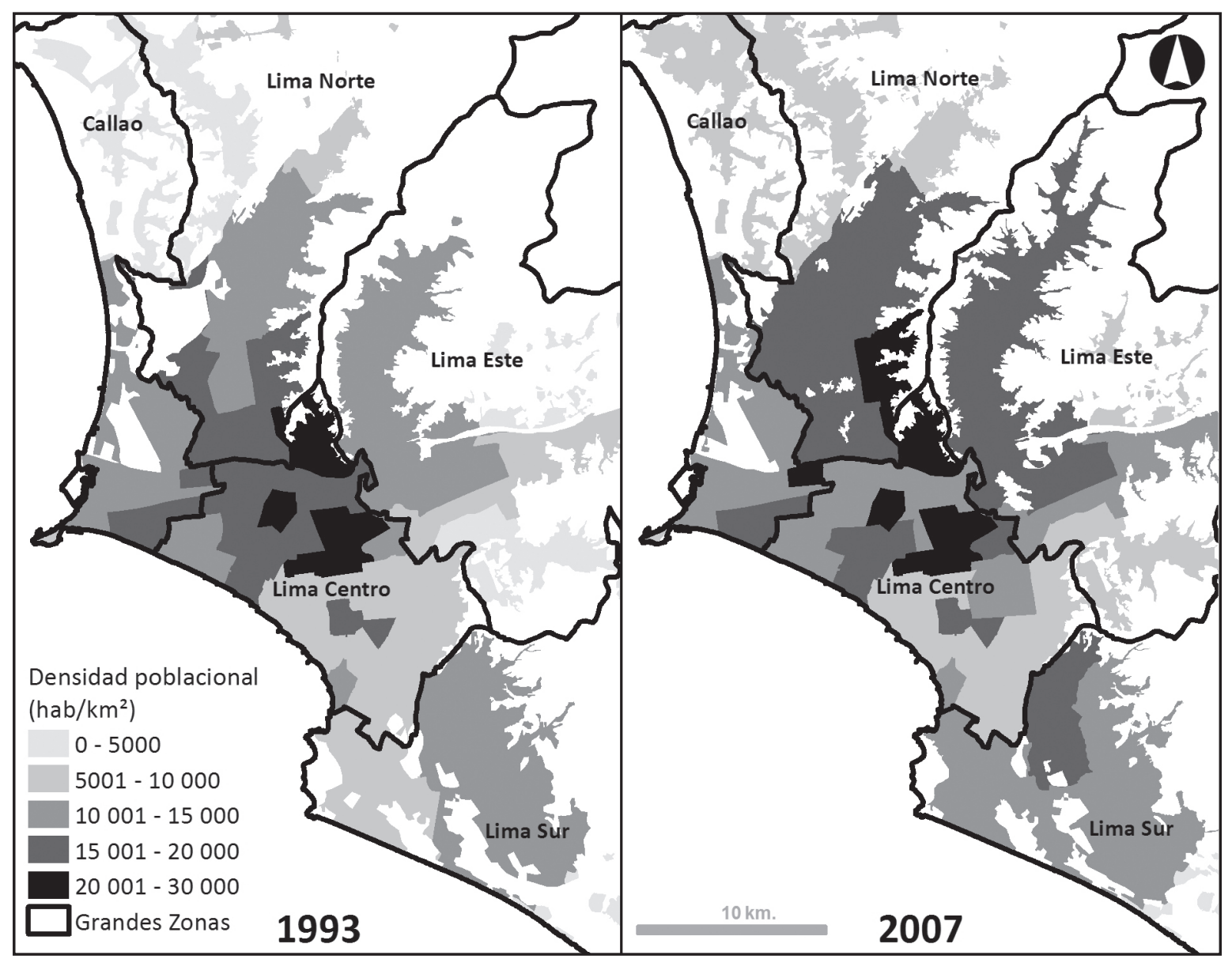

Fuente: INEI. Elaboración propia.

Source: INEI. Elaborated by the author. 


\section{FIGURA 3. ESTRATOS SOCIOECONÓMICOS POR DISTRITO DEL AML 2007.}

FIGURE 3. SOCIOECONOMIC GROUPS DISTRIBUTED BY DISTRICT WITHIN THE MAL, 2007.

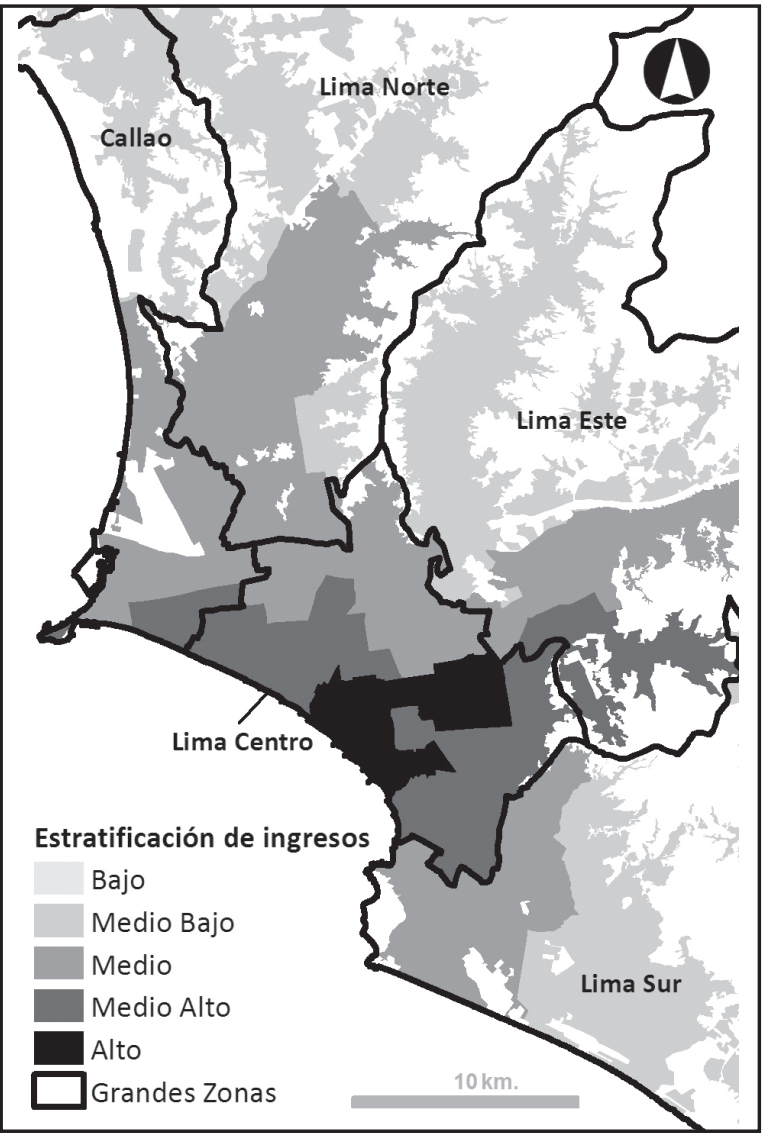

Fuente: INEI. Elaboración propia.

Source: INEI. Elaborated by the author 
de vivienda más ofertado en el mercado formal, a saber, los departamentos. Así, si bien en términos absolutos la oferta de vivienda ha aumentado casi constantemente (sólo en cuatro años se redujo, para recuperarse inmediatamente al año siguiente), en términos relativos la oferta de departamentos se ha encontrado siempre sobre el $80 \%$ del total de viviendas, menos en 2003 (71,3\%) y 2004 (72,7\%). Lo que esto permite apreciar es una tendencia al uso intensivo del suelo, es decir, a la densificación del AML, al menos a partir de la oferta formal.

$\mathrm{Al}$ analizar el periodo observado por grandes zonas del AML, se encuentra que la mayor parte de la oferta de vivienda se concentró en la zona central $(71,2 \%)$, seguida de la zona este de la metrópoli (12,7\%). Esto confirmaría la hipótesis de Calderón (2009), quien sostiene que la pérdida de densidad de la zona central en el último periodo intercensal (1993-2007) estaría revirtiéndose por los nuevos emprendimientos inmobiliarios, pero que no sería sólo a través del FMV, sino que sería producto de toda la acción del mercado formal.

Asimismo, se desprende de esto una concentración de la oferta formal en el área de la ciudad con mayores precios de suelo y, en consecuencia, mayores precios por $\mathrm{m}^{2}$ construido. Como Bensús y Vilela (2014) han demostrado, el valor promedio del $\mathrm{m}^{2}$ construido en el área central ha ido en aumento de forma significativa y ha concentrado los precios process that is currently experiencing the MAL, at least from a formal supply perspective.

The analysis of greater zones within the MAL over the period under review shows that most of the housing supply is concentrated in the central (71.2 percent) and eastern areas of the metropolis (12.7 percent). This confirms the hypothesis proposed by Calderón (2009), which suggests that the loss of density in the central area over the last intercensus period (1993-2007) is being reversed as the result of the construction of new real estate developments within or outside the context of the FMV, including the participation of the formal real estate market as a whole.

Likewise, the above enables us to observe that the formal supply of apartments is concentrated in the most expensive areas of the city, thus generating an increase in the value per square meter. According to Bensús and Vilela (2014), the average value per square meter in the central area has been experiencing a gradual increase; as a result, the highest prices are found in this zone. In other words, the increase in the supply of apartments does not imply a reduction in the value of housing within the formal real estate market; neither does it make them affordable from a neoclassical economic perspective.

This may involve the lack of opportunities for less well-off groups to purchase a property near the 
más altos. En otras palabras, el aumento de la oferta no estaría reduciendo el valor de las viviendas en el mercado formal, haciéndolas más accesibles (en términos económicos), como se esperaría desde la perspectiva de la teoría económica neoclásica.

Lo que esto supondría es la imposibilidad de acceder a vivienda cerca a los mayores nodos de empleo de la metrópoli para gran parte de los estratos menos acomodados. Sin embargo, en los últimos años observados se viene identificando una reducción del peso relativo de la oferta en la zona central (en 2012 llegó al punto más bajo) y un aumento significativo de la oferta en las demás zonas, en particular al este de la ciudad (24,3\% en 2012 y alrededor del 10\% para otros años). Esta última zona no se caracteriza por una alta densidad y, además, concentra la mayor parte de la oferta a los estratos más bajos. En consecuencia, estaría iniciándose un proceso de compactación - por efectos de una lógica del mercado- en zonas de la ciudad cuya morfología ha sido tradicionalmente dispersa.

En este punto debe recordarse que no existe una política nacional ni metropolitana de vivienda social. Como lo documentan diversos trabajos de Calderón (2009, 2011, 2015), el acceso a fondos para la adquisición de viviendas está concentrado en la clase media, lo que supone que siga desatendida la demanda de los estratos más bajos. Esto puede observarse también en la distribución de la oferta según estrato de destino y gran zona en la que se ubicó. largest workplaces in the metropolis. However, the housing supply in the central area of the city has been losing its relative importance over the last years (hitting a record low in 2012); in contrast, other areas are becoming increasingly important, such as the case of the eastern part of the metropolis (24.3 percent in 2012 and 10 percent over preceding years). Apart from being moderately dense, the latter area concentrates a greater share of the supply of housing for lower-income groups. As a result, it appears that traditionally dispersed zones of the city are being affected by an emerging, market-driven compactness process.

It is worth recalling that there are no nationwide or metropolitan policies aimed to address the social housing issue. According to different research conducted by Calderón (2009, 2011 and 2015), the access to funds for the purchase of housing is focused on the middle class; this means that the demands of lower groups are still being ignored. An example of the latter is the distribution of the housing supply according to target economic groups and greater zones.

The housing supply targeted at upper and uppermiddle class groups accounted for 23.1 and 30 percent of the total supply during the period under review, respectively, and it was almost exclusively focused on the central area of the metropolis. As in the specific case of the uppermiddle class, seven percent of apartments were 
FIGURA 4. OFERTA TOTAL DE VIVIENDA POR TIPO 2000-2014 (\%).

FIGURE 4. TOTAL HOUSING SUPPLY, DISTRIBUTED BY TYPE OF DWELLING, 2000-2014 (PERCENTAGE).

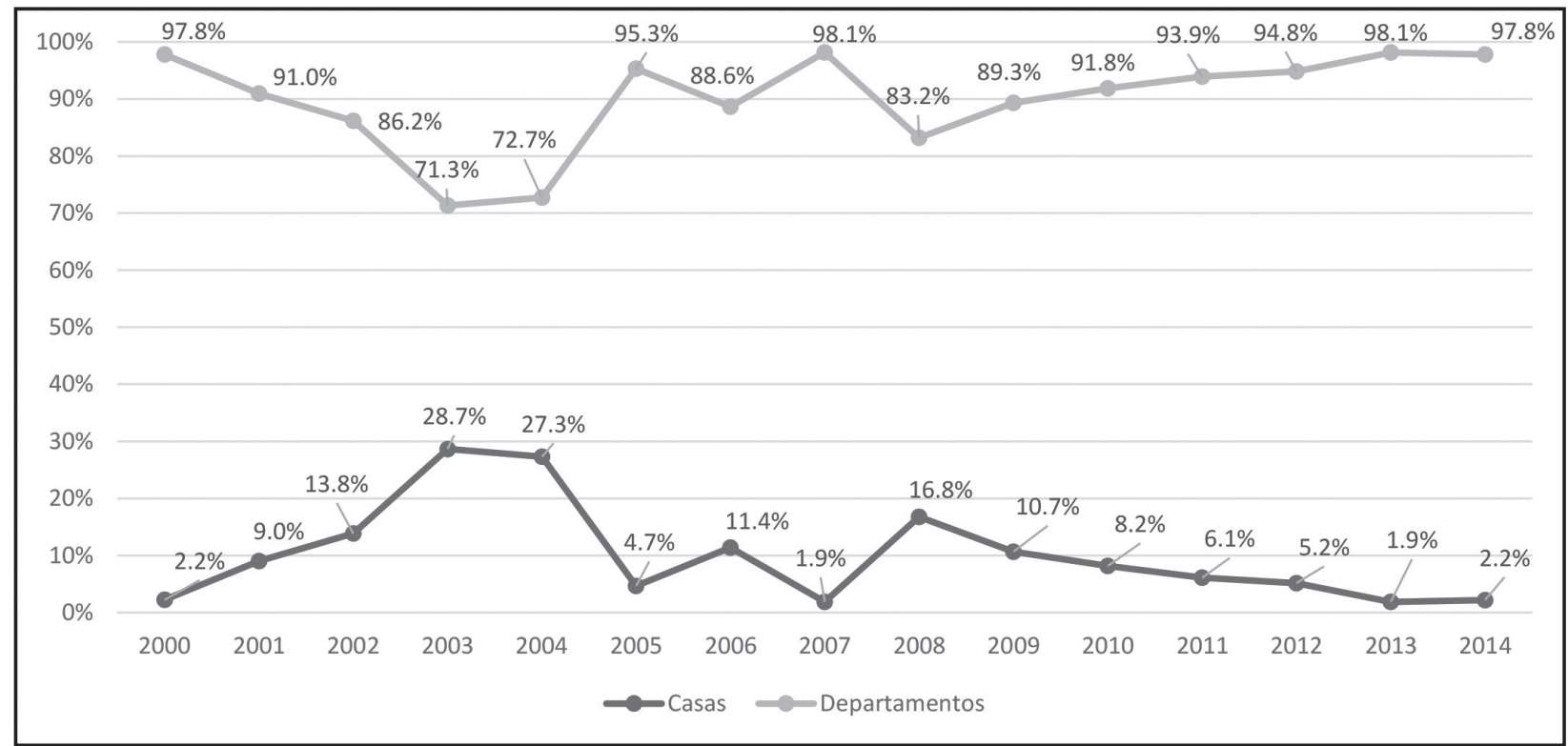

Fuente: CAPECO (2000-2014). Elaboración propia.

Source: CAPECO (2000-2014). Elaborated by the author.

La oferta de vivienda para estratos alto y medio alto, que representó el $23,1 \%$ y $30 \%$ de la oferta total de departamentos en el periodo observado, respectivamente, se concentró casi exclusivamente en la zona central de la metrópoli. Para este segundo estrato, el 7\% de los departamentos se ofreció en la zona este, en gran medida concentrada en el distrito de La Molina, en el cual habita un grupo offered in the eastern area of the city, mainly in La Molina district, which is home to a large number of higher-income households. As for the middle class, the most important supply analyzed over the period under review (33.7 percent) is dispersed in nature, with more than 60 percent of units being located in the central area of the metropolis; however, there is a larger presence 
FIGURA 5. OFERTA TOTAL DE VIVIENDA POR GRANDES ZONAS DEL AML 2000-2014 (\%).

FIGURE 5. TOTAL HOUSING SUPPLY, DISTRIBUTED BY GREATER AREAS WITHIN THE MAL, 2000-2014 (PERCENTAGE).

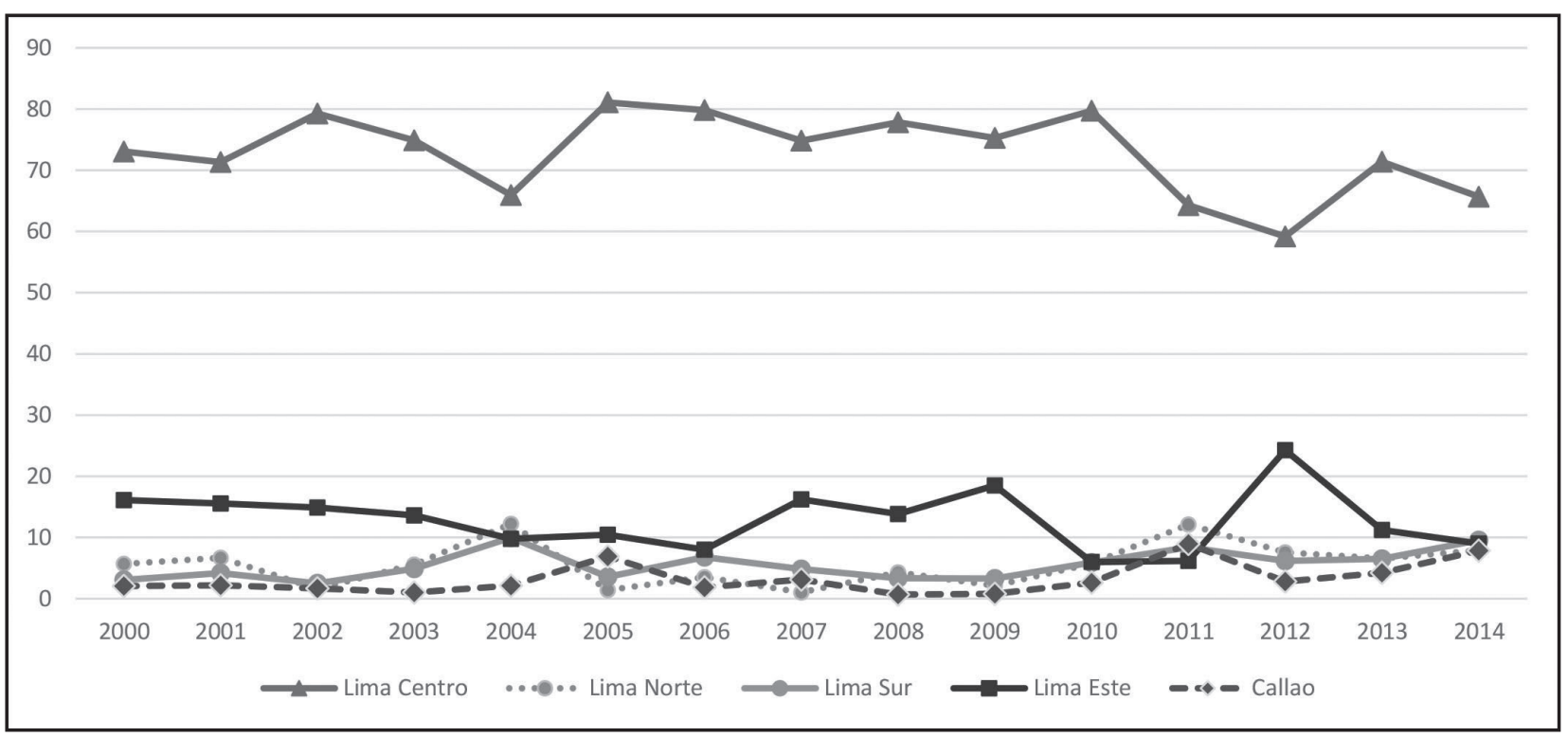

Fuente: CAPECO. Elaboración propia.

Source: CAPECO. Elaborated by the author

importante de personas de estratos altos. La oferta de vivienda para estratos medios, la más importante en el periodo de estudio $(33,7 \%)$ es más dispersa, aún con más del 60\% ubicada en la zona central, pero con presencia más significativa en el sur y este que en los casos anteriores. in southern and eastern parts of the city than in previous cases.

On the other hand, the housing supply targeted at middle-lower and lower class groups accounted for 9.1 and 4.2 percent of the total supply over the period under review, respectively. This 
TABLA 2. OFERTA TOTAL DE DEPARTAMENTOS POR ESTRATO Y GRAN ZONA EN LA OUE SE OFRECIÓ 2000-2014 (\%).

TABLE 2. TOTAL SUPPLY OF APARTMENTS, DISTRIBUTED BY SOCIOECONOMIC GROUP AND GREATER ZONE, 2000-2014 (PERCENTAGE).

\begin{tabular}{lccccc} 
& Alta & Medio alta & Medio & Medio bajo & Bajo \\
\hline Lima Centro & 97,71 & 85,87 & 60,25 & 24,44 & 9,40 \\
Lima Norte & 0,03 & 1,48 & 10,29 & 18,64 & 13,06 \\
Lima Sur & 0,93 & 3,69 & 11,16 & 11,82 & 5,52 \\
Lima Este & 1,30 & 7,07 & 11,71 & 36,66 & 71,63 \\
Callao & 0,02 & 1,89 & 6,59 & 8,44 & 0,38 \\
Total & 100 & 100 & 100 & 100 & 100
\end{tabular}

Fuente: CAPECO. Elaboración propia.

Source: CAPECO. Elaborated by the author.

Por otro lado, la oferta para estratos medio bajos y bajos durante el periodo representó el 9,1\% y 4,2\% del total, respectivamente. Esto confirma la limitada atención de la demanda de vivienda de estos estratos, la cual suele ser suplida por el mercado informal (que implica una expansión horizontal de la ciudad y en zonas de baja habitabilidad). Para el primero de estos estratos, la oferta se encontró dispersa en las cinco zonas observadas, especialmente al este $(36,7 \%)$ y, para los estratos más bajos, más de dos tercios de los departamentos ofrecidos también se ubicaron al este de la metrópoli (71,6\%). confirms the reduced demand for housing on the part of these groups, which is supplied by the informal market (thus facilitating the emergence of horizontal expansion in areas with low habitability standards). In the case of the first of these two groups, supply was distributed over the five areas under review, especially in the eastern part of the city (36.7 percent); as for lower-income groups, more than two thirds of apartments targeted at this segment were located east of the metropolis (71.6 percent).

Examples of these dynamics can be found in the district of Rimac, which was characterized by its 
Un ejemplo de estas dinámicas se encuentra en el distrito del Rímac el cual se caracterizaba por una alta densidad poblacional, baja residencia en departamentos y población de estratos medios y medio bajo principalmente. Desde 2012, la gestión se encontraba trabajando en un proyecto para generar un eje de crecimiento inmobiliario, según señaló una funcionaria, quien manifestó el interés de su municipio por atraer población de estratos más altos que paguen rentas. Esta misma funcionaria respondió, al preguntársele por el potencial crecimiento poblacional y densificación asociado a dicho proyecto "si quieren que vengan [nuevos residentes], pero que no vengan más pobres ya".

Al analizar los datos por zona de la ciudad, se puede apreciar que en la zona central de la metrópoli dos tercios $(67,8 \%)$ de los departamentos ofrecidos estuvieron dirigidos a los estratos alto y medio alto, principalmente para este segundo estrato $(36,1 \%)$. El porcentaje de departamentos para clase alta ofrecidos en otras zonas de la ciudad ha sido mínimo, por ejemplo, solo ha llegado al 3,4\% del total de departamentos ofrecidos en la zona sur. Por otro lado, Callao, Lima este y Lima sur muestran una oferta de alrededor del 15\% para el estrato medio alto. Asimismo, en las zonas norte, sur y en Callao, la oferta para estratos medios supuso más de la mitad de departamentos que se ofrecieron en dichas zonas. Para ese mismo estrato, en Lima este y centro los porcentajes de departamentos ofrecidos fueron de $31,1 \%$ y $28,5 \%$, respectivamente. high population density, low use of apartments and presence of middle and middle-lower class groups. According to an official, since 2012, management initiatives were developing a project intended to generate a pole of real estate growth in the area; this respondent also referred to the interest of the municipality she works in to attract people from higher backgrounds in order to pay taxes. When asked about the potential increase in population and densification associated with the implementation of this project, the official said: "they want them [new residents] to come, but they do not want more poor people living in the district".

The analysis of data for each zone of the city shows that two thirds of apartments offered in the central area of the metropolis (67.8 percent) were aimed at upper and uppermiddle segments, especially in the case of the second group (36.1 percent). In other parts of the city, the percentage of apartments targeted at upper class users was minimal; for instance, these types of housing accounted for 3.4 percent of the total units offered in the southern zone of the city. On the other hand, 15 percent of apartments offered in Callao, East Lima and South Lima were aimed at upper-middle segments. Likewise, more than half of apartments offered in Callao and the northern and southern areas of the city were targeted at middle-income groups. East and Central Lima accounted for 31.1 and 28.5 
TABLA 3. OFERTA TOTAL DE DEPARTAMENTOS POR GRAN ZONA Y ESTRATO AL CUAL SE DIRIGE LA OFERTA 2000-2014 (\%).

TABLE 3. TOTAL SUPPLY OF APARTMENTS, DISTRIBUTED BY GREATER AREA AND SOCIAL GROUP, 2000-2014 (PERCENTAGE).

\begin{tabular}{lcccccc}
\hline & Alta & Medio alto & Medio & Medio bajo & Bajo & Total \\
\hline Lima centro & 31,66 & 36,14 & 28,53 & 3,11 & 0,55 & 100 \\
Lima norte & 0,13 & 7,23 & 56,36 & 27,45 & 8,84 & 100 \\
Lima sur & 3,37 & 17,32 & 58,91 & 16,79 & 3,60 & 100 \\
Lima este & 2,37 & 16,72 & 31,14 & 26,23 & 23,54 & 100 \\
Callao & 0,15 & 15,81 & 62,18 & 21,41 & 0,44 & 100
\end{tabular}

Fuente: CAPECO. Elaboración propia.

Source: CAPECO. Elaborated by the author.

Para los dos estratos más bajos llama la atención la concentración de oferta de departamentos en Lima este, donde juntos representan cerca del $50 \%$ de los departamentos ofertados en el periodo observado. Asimismo, en la zona central del AML la oferta para estos estratos ha sido mínima, llegando a 3,1\% para el medio-bajo y $0,6 \%$ para el bajo. Es decir, el proceso de densificación habitacional que conlleva el mercado formal, al seguir una lógica de rentabilidad tanto de los actores económicos como de los políticos, no atiende la demanda de suelo como valor de uso de los estratos más bajos de la capital. Por el contrario, tiende a concentrarse en zonas de origen informal, elevando el precio del suelo y del $\mathrm{m}^{2}$ construido. percent of apartments aimed at middle class users, respectively.

As for middle-lower and lower-income groups, it is interesting to observe that 50 percent of apartments offered in East Lima are targeted at these two segments over the period under review. Likewise, the percentage of apartments targeted at these segments in the central area of the MAL was minimal -3.1 and 0.6, respectively. In other words, the housing densification process associated with the formal market, which is fueled by the search for returns by economic and political actors, ignores the demands for land -in terms of use values- of poorer segments. On the contrary, it is 
Esta realidad no es ajena a los altos cargos de las empresas inmobiliarias, de hecho, en las entrevistas no tuvieron problema en reconocer que su público objetivo son las clases media y media alta. Asimismo, indicaron que la selección de terreno para construir tiene que ver más con encontrar un terreno vacante con mínimas condiciones para invertir en él, que con cualquier consideración urbanística. Uno de los entrevistados mencionó que "El mercado en el área central está saturado, no hay suelo o está muy caro [...] compramos terrenos donde surge la oportunidad, tenemos gente trabajando en eso".

También se les preguntó por los índices de ocupación de sus nuevos proyectos. Sin dar cifras exactas, todos los representantes de inmobiliarias coincidieron en que muchos de los departamentos de edificios en zonas fuera de la central se encuentran deshabitados, a pesar de estar todos vendidos. Uno de los representantes mencionó que al revisar los datos de los compradores identificaron que muchos de estos residen en distritos de estratos altos de la zona central. En otras palabras, se tratarían de inversiones para revender o alquilar departamentos. Además de estos dos actores -inmobiliarias y compradores-inversores-, como señala Weber (2015), los gobiernos locales tienen un rol importante en incentivar mercados especulativos, en el caso del AML, principalmente buscando atraer población que pague impuestos. Experiencias como estas alertaron a los representantes de la concentrated on informal areas, thus increasing the price of land and values per square meter.

This issue also permeates senior levels within real estate companies; in fact, those interviewed had no problem in recognizing that their goal is to reach middle and upper-middle income groups. Likewise, they also pointed out that the selection of land for development has more to do with finding cheap plots of land than respecting urban standards. In this regard, one interviewee stated that: "The market in the central area is saturated; there are either no developable land or very expensive plots [...] we buy lands in territories that offer opportunities, we have people working on that".

Respondents were also asked about the occupation rates of new projects. Though they did not provide precise information, all real estate representatives agreed on the fact that many of the apartments constructed in buildings outside the central area are uninhabited, despite being completely sold out. One of these real estate representatives said that the analysis of data from buyers reveal that most of them reside in highincome districts located in the central area of the city. In other words, they bought apartments for investment purposes, either to resell or rent them. As Weber suggests (2015), apart from these two actors -real estate companies and buyersinvestors, local governments play a key role in the promotion of speculative markets within the 
Superintendencia de Banca y Seguros -SBS sobre una posible burbuja inmobiliaria. Así, en 2013 la SBS implementó medidas para restringir los préstamos hipotecarios (Benza, 2016). Sin embargo, la vacancia de departamentos no fue un problema mencionado entre los funcionarios de distritos de la zona central.

Siguiendo a Clark y Moir (2015), se identifica la importancia de factores secundarios en el fenómeno de densificación habitacional que ha tenido lugar en el AML en los últimos años. Especialmente importante han sido las dinámicas del mercado inmobiliario y el rol activo de empresas inmobiliarias y bancos en él. Este mercado se ha visto como un eje de crecimiento económico desde los distintos niveles del Estado (principalmente nacional y local). En ese sentido, como el caso analizado por Weber (2015), las políticas, planes (en este caso el PLANMET) o la ausencia de estos, así como los sesgos desarrollistas de los actores involucrados también han sido factores dinamizadores.

Estas ideas se ven resumidas en el comentario de una entrevistada:

Yo creo que una de las grandes falencias que tenemos es que no logramos insertar esto [sus proyectos] en un tema de planificación [...] estamos haciendo ciudad como que a pedacitos y conforme se nos van presentando las oportunidades de negocio (Gerente de inmobiliaria).
MAL as their goal is to attract people able to pay taxes. These cases caused alarm amongst the representatives of the Superintendency of Banks and Insurance-SBS- over the emergence of a real estate bubble. As a result, in 2013, the SBS implemented a series of measures to control the provision of home loans (Benza, 2016). However, the vacancy of apartments was not referred to by officials from central districts.

According to Clark and Moir (2015), it is possible to identify the importance of secondary factors in the housing density phenomenon that has been experiencing the MAL over the last years. In this context, real estate dynamics and the active role played by real estate companies and banks are particularly important. This type of market is seen by different State levels (especially by national and local scales of government) as a pole of economic growth. In this sense, as in the case analyzed by Weber (2015), policies, plans (PLANMET), the lack of both and the biased developmental approaches of relevant actors are also regarded as driving forces within this process.

The above is summarized by one respondent:

One of our major flaws is that we cannot insert [their projects] in a planning context [...], we are building at a slow pace and according to business opportunities. (Real estate manager). 
Como se expresa en la cita, estas dinámicas tienen efectos sobre el espacio. Son dos los principales efecto que se han podido identificar: i) la intensificación de la concentración de estratos altos en la zona central de la ciudad, lo cual conllevaría mayor segregación socio-espacial; y, ii) la expansión del modelo compacto de ciudad a zonas tradicionalmente difusas, principalmente al Este de la metrópoli.

Otras ciudades latinoamericanas como Santiago de Chile o Buenos Aires, se caracterizan por la aparición de barrios de ingresos altos en zonas periféricas en las últimas décadas. En el caso de Sao Paulo, existe proximidad espacial entre distintos estratos, pero persiste la segregación a través de enclaves fortificados (Caldeira, 2007). En el caso de Lima, se ha intensificado la homogenización del área central para estratos altos.

Si bien la densificación del área central forma parte de los objetivo del PLANMET, el proceso no ha estado enfocado en la demanda de vivienda, principalmente de los residentes más vulnerables de la metrópoli. La lógica de actores públicos y privados ha estado enfocada en la circulación de capital, en oportunidades económicas, lógica de mercado (Abramo, 2012). Sin embargo, la dinámica es más compleja e involucra las decisiones, disposiciones y sesgos de los distintos actores involucrados (Weber, 2015). A medida que se ha ido cambiando la normativa edificadora, generado incentivos
As the above quotation says, these dynamics affect space. In this regard, two major consequences have been identified: i) greater concentration of higher-income groups in the central area of the city and the potential intensification of sociospatial segregation; and ii) the expansion of the compact city model to traditionally diffused areas, which are mainly located in the eastern part of the metropolis.

Other Latin American cities such as Santiago in Chile or Buenos Aires are characterized by the emergence of high-income neighborhoods in peri-urban areas over the last decades. As for the case of Sao Paulo, though there is spatial proximity among different socioeconomic groups, the presence of fortified gated communities reveals that segregation is still an issue (Caldeira, 2007). As for Lima, the central area of the city has become increasingly homogenized as it is home to most of the population from higher backgrounds.

While the densification of the central area of the city is part of the objectives of PLANMET, this process has not been focused on the housing demand, especially when it comes to addressing the needs of the most vulnerable neighbors of the metropolis. The logics governing the actions taken by public and private actors have been focused on the flow of capital, economic opportunities and market-oriented 
y, como consecuencia de las construcciones, cambiando la ciudad, los actores económicos también se ha tenido que adaptar. Es decir, no solo las dinámicas económicas afectan a la densificación, sino que la densificación también ha influido en esos factores.

\section{Conclusiones}

Cambios en el modelo económico y en políticas públicas iniciados en la década de 1990 tuvieron efectos sobre la gestión y planificación urbanas, y el mercado inmobiliario. Estos incluyen decisiones de los distintos gobiernos de turno para, por ejemplo, la reactivación del Ministerio de Vivienda y fondos para créditos en el acceso a vivienda, así como flexibilización en la normativa de construcción. Pero estos cambios no fueron solo ideas de los presidentes de turno y sus equipos, sino también el resultado de la presión de actores económicos como bancos e inmobiliarias. Todos estos cambios se dieron en un contexto de expansión de la economía global que dio un nuevo rol a los gobiernos locales para la gestión de sus territorios y generación de fondos.

La relevancia de abordar este proceso desde la densificación habitacional se sustenta en tres puntos, el primero es que este proceso está vinculado al principal producto del mercado logics (Abramo, 2012). However, these dynamics are complex in nature and involve decisions, regulations, and biased opinions on the part of relevant actors (Weber, 2015). The amendments made to building regulations, the granting of incentives and the construction of buildings have modified the city and led to the adaptation of economic actors. In other words, densification and economic dynamics influence each other.

\section{Conclusions}

Changes in the economicmodel and publicpolicies, which began in the 1990s, had consequences on urban planning, urban management and the real estate market. These included the decisions made by different governments to revitalize the Ministry of Housing, the provision of funds for credit to access housing, and the relaxation of building standards. However, these modifications were not only conceived by incumbent presidents and their administrations, but also as the result of the pressure exerted by economic actors, such as banks and real estate companies. All of these changes were introduced within the context of a global economic expansion in which local 
inmobiliario -viviendas en departamentos. Asimismo, resulta relevante puesto que se relaciona con los dos principales efectos socio-espaciales para la metrópoli: la intensificación de los patrones de segregación urbana y la expansión del modelo compacto de construir ciudad a zonas tradicionalmente dispersas. Por último, una dimensión no abordada en este trabajo pero que requiere mayor investigación se vincula al debate actual sobre la idoneidad de ciudades más densas en relación a mejoras de accesibilidad y sostenibilidad ambiental.

En el caso del AML, entre los más resaltantes objetivos en el principal documento de planificación de la metrópoli-PLANMET- se propuso como un objetivo general la densificación del área central de la ciudad, y esto se hizo aplicando el principio de subsidiariedad estatal. En otras palabras, se sostiene que la planificación se limitó a la propuesta de densificación de cierta zona de la metrópoli y no se articuló con otras políticas salvo la de incentivación de la economía nacional. En consecuencia, las dinámicas de densificación no siguieron una lógica de planificación, sino la lógica del mercado. A escala de los gobiernos locales, esto incluyó el enfoque en la atracción de inversión, así los funcionarios comienzan a asumir roles de intermediarios, conciliadores y recurren a lógicas y prácticas informales (Roy, 2009) para regular e incentivar la actividad inmobiliaria. governments took on new responsibilities to manage their territories and generate new funds.

The importance of addressing this process from a housing density perspective is threefold; the first refers to the relationship that exists between this process and the provision of the main product generated by the real estate market -housing apartments. Likewise, this phenomenon is associated with two of the main socio-spatial characteristics that affect the metropolis: the intensification of urban segregation patterns and the expansion of the compact city model to traditionally dispersed areas. Lastly, there is a dimension that should be further explored; such an issue refers to the debate on the suitability of most dense cities to provide better accessibility and environmental sustainability.

As for the MAL, one of the most important objectives laid out in the main planning document for the metropolis -PLANMETinvolves the densification of the central area of the city through State subsidies. In other words, planning initiatives have only focused on the densification of a specific area of the metropolis, ignoring other policies -with the exception of that intended to boost national economy. As a result, densification dynamics did not follow planning patterns; instead, they were governed by market-oriented models. At the local government scale, these dynamics involved the 
En resumen, las dinámicas del mercado inmobiliario en el AML han conllevado a y se han visto influenciadas por un proceso de densificación habitacional, principalmente en la zona central, la cual aparentemente estaría recuperando la densidad poblacional perdida en el periodo 1993-2007. Y estas son el resultado de diversos factores como la demanda de vivienda de la población metropolitana, la competencia entre gobiernos locales para atraer inversión inmobiliaria y población que pague impuestos, las presiones e intereses de actores económicos y las personas e instituciones a cargo del diseño de políticas públicas. Sin embargo, se deja de lado una perspectiva conjunta de la metrópoli y no se atiende la demanda de vivienda de los estratos más bajos.

\section{Agradecimientos}

Agradezco los comentarios de mis colegas del CIAC (PUCP) y de Karen Chapple (UC Berkeley) a versiones iniciales de este trabajo. También agradezco los comentarios de dos revisores anónimos. attraction of investors. As a result, officials took on intermediary and conciliatory roles, thus resorting to informal practices (Roy, 2009) to regulate and promote the real estate business.

To conclude, the dynamics of the real estate market within the MAL have led to the emergence of an influencing housing densification process that is mainly focused on the central area of the city, which is apparently recovering the population lost over the period 1993 to 2007. These dynamics are the result of factors such as the housing demand within the metropolis, the competition among local governments to attract investment and people able to pay taxes and the interests and pressure exerted by economic actors and the institutions and people in charge of designing public policies. However, the metropolis is not addressed as a whole, thus ignoring the housing demands of lower-income groups.

\section{Acknowledgments}

I would like to thank my colleagues at CIAC (PUCP) and Karen Chapple (UC Berkeley) for their comments on the early drafts of this work. I would also like to thank the anonymous reviewers for their comments on this paper. 


\section{Referencias bibliográficas}

Abramo, P. (2012). La ciudad com-fusa: mercado y producción de la estructura urbana en las grandes metrópolis latinoamericanas. EURE, 38(114), 35-69. https://doi.org/10.4067/ S0250-71612012000200002.

Alfonso, ó. (2012). Mercado inmobiliario y orden residencial metropolitano en Bogotá. EURE, 38(114), 99-123. https://doi.org/10.4067/ S0250-71612012000200004.

Angel, S., Parent, J., Civco, D. \& Blei, A. (2010). The persistent decline in urban densities: Global and historical evidence of "sprawl". Cambridge: Lincoln Institute of Land Policy.

Arbury, J. (2005). From urban sprawl to compact city. An analysis of urban growth management in Auckland (Thesis MA Geography and Environmental Science, sin publicar). Auckland University, Auckland.

Basualdo, J.L. (2013). Planes urbanos, la llegada al territorio de las estrategias del municipio. En D.A. Erba (Ed.), Definición de políticas de suelo urbanas en América Latina. Teoría y práctica (pp. 263-272). Cambridge: Lincoln Institute of Land Policy.

Bensús, V. y Vilela, M. (2014). La mercantilización del desarrollo urbano en el Área Metropolitana de Lima. Mercado inmobiliario formal y gestión de la densidad urbana 2008-2012. En II Segundo Seminario Internacional: Derecho a la Ciudad en América Latina. Lima, Perú.
Benza, P. (2016). Inmobiliari en venta: la deuda asciende a S/.363 millones. Semana Económica. Recuperado de: http://semanaeconomica.com/article/ sectores-y-empresas/ inmobiliario/207564-inmobiliari-en-venta-la-deuda-asciende-a-s-363-millones/.

Brenner, N. (1998). Globalisation as reterritorialisation: The re-scaling of urban governance in the European Union. Urban Studies, 36(3), 431-451. https://doi.org/10.1080/0042098993466.

Caldeira, T. (2007). Ciudad de muros. Barcelona: Gedisa.

Calderón, J. (2015). Programas de vivienda social nueva y mercados de suelo urbano en el Perú. EURE, 41(122), 27-47. https:// doi.org/10.4067/ S0250-71612015000100002.

(2011). Titulación de la propiedad y mercado de tierras. EURE, 37(111), 47-77. https:// doi. org/10.4067/S0250-71612011000200003.

(2009). El efecto Mivivienda. Política de vivienda para la clase media y diferenciación social. Ecuador Debate, (76), 107-122.

(2005). La ciudad ilegal. Lima en el siglo $X X$. Lima: Universidad Nacional Mayor de San Marcos.

(1999). Las ideas urbanas en el Perú (1958-1989). Lima: Instituto de Desarrollo Urbano-CENCA.

Cervero, R. (1998). The transit metropolis. Washington DC: Island Press. 
Chion, M. (2002). Dimensión metropolitana de la globalización: Lima a fines del siglo XX. EURE, 28(85), 71-87. https://doi.org/10.4067/ S0250-71612002008500005.

Clark, G. \& Moir, E. (2015). Density: Drivers, dividends and debates. Londres: Urban Lab Institute. Recuperado de: http://europe.uli.org/wp-content/ uploads/sites/3/ULI-Documents/Density-Drivers-Dividends-Debates.pdf.

Ciccolella, P. (2012). Revisitando la metrópolis latinoamericana más allá de la globalización. Revista Iberoamericana de Urbanismo, (8), 9-21. Recuperado de: http://upcommons.upc.edu/bitstream/ handle/2099/13012/08_01_Ciccolella.pdf.

Ciccolella, P. y Mignaqui, I. (2009). Capitalismo global y transformaciones metropolitanas: enfoques e instrumentos para repensar el desarrollo urbano. En H. Poggiese y T. Cohen (Comps.), Otro desarrollo urbano: ciudad incluyente, justicia social y gestión democrática (pp. 35-50). Buenos Aires: CLACSO.

Declève, B., Ananian, P., Anaya, M. y Lescieux, A. (2008). Densités bruxelloise et formes d'habiter. Bruselas: Ministère de la Region de Bruxelles-Capitale.

Deler, J.P. (1975). Lima 1940-1970. Aspectos del crecimiento de la capital peruana. Lima: Centro de Investigaciones Geográficas.

Fainstein, S. (2001). The city builders: property development in New York and London 1980-2000. Kansas: University Press of Kansas.

Fernández de Córdova, G., Moschella, P. y Bogdanovich, L. (2011). Los sectores segregados periféricos ¿son los nuevos espacios para el desarrollo urbano de la metrópoli de Lima y Callao? En C.d. Mattos, W. Ludeña y L. Fuentes (Eds.), Lima-Santiago. Reestructuración y cambio metropolitano (pp. 237-272). Lima: Centro de Investigación de la Arquitectura y la Ciudad, Pontificia Universidad Católica del Perú, Instituto de Estudios Urbanos y Territoriales, Pontificia Universidad de Chile.

Gonzales, E. y Del Pozo, J.M. (2012). Lima, una ciudad policéntrica. Un análisis a partir de la localización del empleo. Investigaciones Regionales, (23), 29-52.

Gonzales, E., Del Solar, V. y Del Pozo, J.M. (2011). Lima metropolitana después de las reformas neoliberales: transformaciones económicas y urbanas. En: C.d. Mattos, W. Ludeña y L. Fuentes (Eds.), LimaSantiago. Reestructuración y cambio metropolitano (pp. 135-176). Lima: Centro de Investigación de la Arquitectura y la Ciudad, Pontificia Universidad Católica del Perú, Instituto de Estudios Urbanos y Territoriales, Pontificia Universidad de Chile.

Gotham, K.F. (2009). Creating liquidity out of spatial fixity: the secondary circuit of capital and the subprime mortgage crisis. International Journal of Urban and Regional Research, 33(2), 355-371. https://doi. org/10.1111/j.1468-2427.2009.00874.x.

Hall, P. (1996). Ciudades del mañana. Historia del urbanismo en el siglo XX. Barcelona: Ediciones del Serbal.

Harvey, D. (2008). El derecho a la ciudad. New Left Review, (53), 22-39. 
(1989). From managerialism to entrepreneurialism: the transformation in urban governance in late capitalism. Geografiska Annaler: Series B, Human Geography, 71(1), 3-17. https://doi. org/10.1080/04353684.1989.11879583.

Hermida, M. A., Hermida, C., Cabrera, N., \& Calle, C. (2015). La densidad urbana como variable de análisis de la ciudad: El caso de Cuenca, Ecuador. EURE, 41(124), 25-44. https://doi.org/10.4067/ S0250-71612015000400002.

Instituto Nacional de Estadística e Informática. (2007). Perú: censos nacionales 2007 XI de población y VI de vivienda. Lima: Autor.

Janoschka, M. e Hidalgo, R. (2014). La ciudad neoliberal: estímulos de reflexión crítica. En R. Hidalgo y M. Janoschka (Coords.), La ciudad neoliberal. Gentrificación y exclusión en Santiago de Chile, Buenos Aires, Ciudad de México y Madrid (pp. 7-32). Santiago de Chile: Pontificia Universidad Católica de Chile.

Jaramillo, S. (2003). Los fundamentos económicos de la participación en plusvalías. Bogotá, Colombia: Universidad de los Andes, CEDE, Lincoln Institute of Land Policy.

Lefebvre, H. (2013). La producción del espacio. Madrid: Capitán Swing.

Logan, J. \& Molotch, H. (2007). Urban fortunes: the political economy of place. 20th ed. Berkeley, CA: University of California Press.

Matos Mar, J. (1984). Desborde popular y crisis del Estado. Lima: Instituto de Estudios Peruanos.
Mattos, C.d. (2008). Globalización, negocios inmobiliarios y mercantilización del desarrollo urbano. En C. Pereira y R. Hidalgo (Coords), Producción inmobiliaria y reestructuración metropolitana en América Latina (pp. 23-40). Santiago de Chile: Pontificia Universidad Católica de Chile y Universidad de Sao Paulo.

(2002). Transformación de las ciudades latinoamericanas. ¿Impactos de la globalización? EURE, 28(85), 5-10. https://doi.org/10.4067/ S0250-71612002008500001.

Molotch, H. (1976). The city as a growth machine. Toward a political economy of place. American Journal of Sociology. Vol. 82, No 2, 309-332. Recuperado de: http://www.jstor.org/stable/2777096.

Municipalidad Metropolitana de Lima. (1992). Plan de desarrollo metropolitano de Lima y Callao 19902010. Lima: Autor.

Navarro, J.y Ortuño, A. (2011). Aproximación a la génesis de la contribución de la densidad en la noción de "ciudad compacta". EURE, 37(112), 23-41. https:// doi.org/10.4067/S0250-71612011000300002.

Orellana, A. (2011). Gestión municipal a escala metropolitana: patrones y consecuencias para el caso del Área Metropolitana de Santiago. En C.d. Mattos, W. Ludeña y L. Fuentes (Eds.), Lima-Santiago. Reestructuración y cambio metropolitano (pp. 333-350). Lima: Centro de Investigación de la Arquitectura y la Ciudad, Pontificia Universidad Católica del Perú, Instituto de Estudios Urbanos y Territoriales, Pontificia Universidad de Chile. 
Pereyra, 0. (2006). Forma urbana y segregación residencial en Lima. Debates en Sociología, (31), 69-106.

(2004). Políticas sociales en la Lima neoliberal. Un acercamiento desde cuatro estudios de caso en Lima norte. Lima: Alternativa Centro de Investigación Social y Educación Popular.

Portes, A. \& Roberts, B. (2005). The free-market city: Latin American urbanization in the years of the neoliberal experiment. Studies in Comparative International Development, 40(1), 43-82. https:// doi.org/10.1007/BF02686288.

Riofrío, G. (1982). La problemática urbana y regional. Presentado a I Congreso Peruano de Sociología, Huacho, Perú.

Rodríguez, A. (1969). Notas para la interpretación del desarrollo físico de las barriadas. Lima: DESCO.

Roy, A. (2009). Why India cannot plan its cities: Informality, insurgence and the idiom of urbanization. Planning Theory, 8(1), 76-87. https://doi. org/10.1177/1473095208099299.

(2005). Urban informality: toward an epistemology of planning. Journal of the American Planning Association, 71(2). https://doi. org/10.1080/01944360508976689.

Ugarteche, Ó. y Martínez-Ávila, E. (2013). La gran mutación. México D.F.: Universidad Nacional Autónoma de México.

Weber, R. (2015). From boom to bubble: How finance built the new Chicago. Chicago, IL: University of Chicago Press. 